\title{
The Decorated Ceramic Sherds, Plain Rim Sherds, and Clay Pipe Sherds from the Stallings Ranch Site (41LR297), Lamar County, Texas
}

Timothy K. Perttula

Follow this and additional works at: https://scholarworks.sfasu.edu/ita

Part of the American Material Culture Commons, Archaeological Anthropology Commons, Environmental Studies Commons, Other American Studies Commons, Other Arts and Humanities Commons, Other History of Art, Architecture, and Archaeology Commons, and the United States History Commons

Tell us how this article helped you.

This Article is brought to you for free and open access by the Center for Regional Heritage Research at SFA ScholarWorks. It has been accepted for inclusion in Index of Texas Archaeology: Open Access Gray Literature from the Lone Star State by an authorized editor of SFA ScholarWorks. For more information, please contact cdsscholarworks@sfasu.edu. 
The Decorated Ceramic Sherds, Plain Rim Sherds, and Clay Pipe Sherds from the Stallings Ranch Site (41LR297), Lamar County, Texas

\section{Creative Commons License}

(c) (1) (8)

This work is licensed under a Creative Commons Attribution-NonCommercial 4.0 International License 


\title{
The Decorated Ceramic Sherds, Plain Rim Sherds, and Clay Pipe Sherds from the Stallings Ranch Site (41 LR297), Lamar County, Texas
}

\author{
Timothy K. Perttula
}

\section{Introduction}

Excavations at the Gene and Ruth Ann Stallings Ranch site (41LR297) during the 2005 and 2006 Texas Archeological Society Field Schools (see Skinner 2007, 2016), as well as 2004 excavations by the Valley of the Caddo Archeological Society, recovered an interesting assemblage of prehistoric ceramics. In this article, I analyze the 88 decorated sherds, the 99 plain rims, and the 67 clay pipe sherds found during that work. In addition to characterizing the assemblage of vessel sherds and pipes in terms of decorative style and various technological attributes (i.e., temper and paste, firing conditions, surface treatment, etc.), I am also concerned with establishing the temporal and cultural affiliation of the recovered ceramics, particularly with respect to determining whether the ceramics found at the Stallings site are primarily from a Fourche Maline Woodland period occupation or a later, post-A.D. 800 Caddo ancestral occupation.

\section{Site Setting}

The Gene and Ruth Stallings Ranch site is on an alluvial terrace of Pine Creek, a northeastward flowing tributary to the Red River (Figure 1); the site is ca. $15 \mathrm{~km}$ upstream from the confluence of Pine Creek with the Red River (Skinner 2016:4). The area includes both Blackland Prairie and Post Oak Savannah biotic zones (Diggs et al. 2006). According to Skinner (2016:23), the Stallings site "is essentially a midden deposit that covers an oval-shaped area that is 330 meters north-south by 240 meters east-west" (see also Bruseth et al. 2009); Skinner's map of the site indicates that TAS excavations were in an area ca. 70 x $60 \mathrm{~m}$ in size, ca. 1 acre (Skinner 2016:Figure 6), and included 2391 x 1 m excavation units.

The test excavations at the site reported by Bruseth et al. (2009:200 and Table 1) recovered 506 ceramic vessel sherds and four ceramic pipe sherds from long-stemmed Red River pipes. The analysis of these artifacts is very cursory:

The sherds are mostly from grog-tempered Williams Plain vessels, as defined by the lack of decoration and the occasional sherd that showed the classic stilted body-base juncture. Only five decorated sherds were found; three have parallel incised lines, one has possible parallel engraved lines, and another has parallel pinched rows. None is large enough to be typed.

Bruseth et al. (2009:203) suggest that the principal occupation at the site was by a late Fourche Maline (ca. A.D. 700-800) group. The decorated sherds and the pipe stems were considered to be part of a later ancestral Caddo occupation, but Bruseth et al. (2009) did not make any comments on the age or affiliation of the Caddo occupation at the Gene and Ruth Stallings Ranch site. 


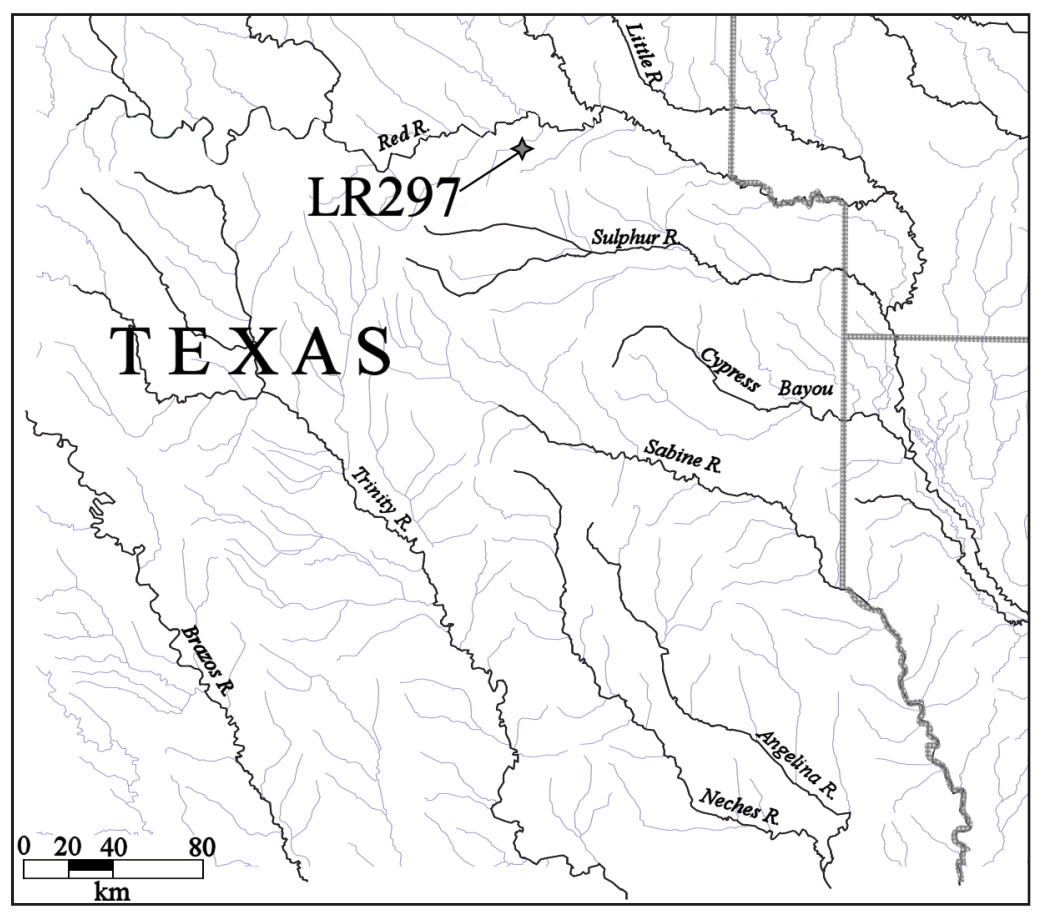

Figure 1. The location of the Gene and Ruth Stallings Ranch site (41LR297) in East Texas.

\section{Methods of Analysis}

Detailed analysis of the decorated ceramic vessel sherds and plain rim sherds from the Gene and Ruth Ann Stallings Ranch site (Appendix 1 and 2) is based on differences in temper, type of sherd (i.e., rim, body, or base), rim and lip form (cf. Brown 1996: Figure 2-12), decoration (if present), surface treatment (smoothing, burnishing, or polishing; see Rice 1987), and firing conditions (cf. Teltser 1993). Sherd cross-sections were inspected macroscopically and with a 10X hand lens to determine the character of the paste and its inclusions. Determining the firing conditions is based on the identification of the firing core in the sherd cross-sections and the identification of oxidation patterns as defined in Teltser (1993:535-536 and Figure 2a-h).

More specifically, the following attributes were employed in the analysis of the vessel ceramics: (a) temper, the deliberate and indeterminate materials found in the paste (Rice 1987:411), including a variety of tempers (grog or crushed sherds, burned bone, hematite, and burned mussel shell) and "particulate matters of some size;" (b) although most of the sherds are small and thus from indeterminate vessel forms, where sherds were large enough, vessel form categories include open containers (bowls and carinated bowls) and restricted containers, including jars and bottles. Other form attributes include rim profile (outflaring or everted, direct or vertical, and inverted) and lip profile (rounded, flat, or folded to the exterior). There were no base sherds, so base shape could not be recorded. Observations on ceramic sherd cross-sections permit consideration of oxidation patterns (Teltser 1993:Figure 2), namely the conditions under which a vessel was fired and then cooled after firing. Finally, wall thickness was recorded in millimeters $(\mathrm{mm})$, using a vernier caliper, along the mid-section of the sherd.

With respect to interior and exterior surface treatment on the sherds, the primary methods of finishing the surface of the vessels includes smoothing, burnishing, and polishing, although a few sherds may still have scraping marks from initial surface treatment work by the potter. Smoothing creates "a finer and more regular surface...[and] has a matte rather than a lustrous surface" (Rice 1987:138). 
Burnishing creates an irregular lustrous finish marked by parallel facets left by the burnishing tool (perhaps a smoothed pebble or bone). A polished surface treatment is marked by a uniform and highly lustrous surface finish, done when the vessel is dry, but without "the pronounced parallel facets produced by burnishing leather-hard clay" (Rice 1987:138).

Decorative techniques present in the Stallings site ceramic sherd collection from the TAS excavations include engraving, incising, punctating, and pinching, and on certain sherds, combinations of decorative techniques (i.e., incised-punctated) created the decorative elements and motifs. Engraving was done with a sharp tool when the vessel was either leather-hard or after it was fired, while the other decorative techniques were executed with tools (incising or punctating with wood or bone sticks or dowels) or fingers (pinching or fingernail punctating) when the vessel was wet or still plastic.

Attributes of rim form, temper, paste, firing conditions, surface treatment, and wall thickness are analyzed for the long-stemmed Red River style (cf. Hoffman 1967) pipe sherds in the Stallings site ceramic assemblage (Appendix 3). Measurements were also taken when available of bowl height, diameter and wall thickness; stem thickness; exterior stem diameter; and interior stem or stem hole diameter. These particular measurements are useful in assigning the pipe sherds to one or more of the defined Red River pipe varieties.

\section{The Decorated Ceramic Sherd Assemblage}

Only 88 decorated sherds (Appendix 1) are present in the Stallings site ceramic collection out of a total of more than 3150 sherds and sherdlets (S. Alan Skinner, November 2007 personal communication). Disregarding the sherdlets $(n=1816)$, the plain/decorated ratio $(P / D R)$ in this assemblage is 14.3:1 (i.e., 1255 plain and 88 decorated sherds). This is a moderately high P/DR ratio for East Texas pottery-bearing sites, indicating that the assemblage is dominated by plain ware vessels and vessels with decoration confined almost exclusively to a small portion of the upper part of the vessel. By way of comparison, preA.D. 1200 Caddo sites in the lower Red, middle Sabine, and Neches-Angelina River basins have P/DR values between 2.97-4.80:1 (Perttula 2004:390; Bruseth and Perttula 2006). Closer to the Stallings site, at the Ray site (41LR135), thought to have been principally occupied between ca. A.D. 800-1000 by Bruseth et al. (2001:212), the P/DR value is 56.6:1. At the slightly later Early Caddo component at the Sam Kaufman/Roitsch site (41RR16) on the middle reaches of the Red River-specifically the East Mound excavations - the P/DR in the ceramic assemblage is 48.6:1 (Skinner et al. 1969:Tables 5 and 6). The ceramic sherd assemblage recovered from the Stallings site by Bruseth et al. (2009) is 100:1.

The 88 decorated sherds are readily separated into fine wares $(n=27)$ or utility wares $(n=61)$, following the distinctions discussed by Schambach and Miller (1984) at the Cedar Grove site (3LA97) in the Great Bend area in southwestern Arkansas. These distinctions include apparent differences in temper, surface treatment, vessel forms, and decorative methods. Utility wares generally are jars and simple bowls used for the cooking and storage of foods, have a coarse temper, and lack burnishing, polishing, or slipping on interior and exterior vessel sherd surfaces. Such vessel sherds are decorated with brushing, incising, punctations (tool, cane, or fingernail), and appliqued elements, either by themselves or in combination with one or more of these decorative methods (see Perttula et al. 1995; Schambach and Miller 1984; Suhm and Jelks 1962). Fine wares, on the other hand, at the site consist principally of engraved and slipped vessel sherds from carinated bowls, some simple bowls, and bottles. The fine ware vessel sherds more frequently are smoothed or burnished on the exterior vessel surface, and as will be discussed in more detail below, the fine ware vessels from the Stallings ranch site were made, fired, and likely used in different ways than were the utility ware vessels. 
All 27 fine ware sherds are from engraved Caddo pottery vessels (Table 1), including bowls, carinated bowls, and four bottle sherds. With the exception of one unique rim sherd (Figure 2d-e) from a Clark Engraved vessel (Perino 1994:29 and Figure 14a-h), the other engraved fine wares have relatively simple geometric, straight-line, or curvilinear (Figure 2a) decorative elements consisting of horizontal (Figure 2c), opposed, or concentric circular motifs. There is a single red-slipped engraved rim sherd (from the Clark Engraved vessel) in the Stallings site fine wares, but no plain red-slipped sherds as there are in post-A.D. 1100/1200 Caddo sites of Sanders phase affiliation in this part of the Red River basin (Perttula 2008; Perttula et al. 2016; Prikryl 2008; Skinner et al. 1969).

Table 1. Fine ware sherd decorative elements from the Stallings site.

\begin{tabular}{lll}
\hline Decorative element & Rim sherd & Body sherd \\
\hline $\begin{array}{l}\text { curvilinear engraved lines } \\
\text { curvilinear engraved lines, } \\
\text { closely-spaced }\end{array}$ & - & 3 \\
$\begin{array}{l}\text { curvilinear engraved lines, } \\
\text { widely-spaced }\end{array}$ & - & 1 \\
$\begin{array}{l}\text { single straight engraved line } \\
\text { parallel engraved lines } \\
\text { parallel engraved lines, } \\
\text { closely-spaced } \\
\text { parallel engraved lines, } \\
\text { widely-spaced }\end{array}$ & - & 3 \\
$\begin{array}{l}\text { opposed and parallel engraved } \\
\text { lines } \\
\text { opposed engraved lines } \\
\text { horizontal engraved lines } \\
\text { hatched engraved zone }\end{array}$ & - & 1 \\
scroll element & - & 2 \\
\hline \begin{tabular}{l} 
Totals \\
\hline
\end{tabular} & - & 6 \\
\hline
\end{tabular}

Three rims and a bottle neck have horizontal engraved lines, and are likely (at least in the case of the bottle sherd) from Holly or Hickory Engraved vessels (cf. Suhm and Jelks 1962:Plate 40e). All the body sherds may also be from these same engraved types, which are characteristic pottery styles in pre-A.D. 1150 Caddo pottery assemblages across the middle reaches of the Red River basin.

There is one engraved and red-slipped rim sherd (see Figure 2d-e) from a Clark Engraved carinated bowl with a direct rim and a rounded, exterior folded lip; it is tempered with grog. This particular pottery type has been found in a few sites along the Red River in what appears to be a ca. A.D. 1300-1500, or early McCurtain phase, Caddo archaeological contexts (see Perino 1994). Its presence at the Stallings site is evidence that there was some use of the site by the Caddo during this time period, but that use does not appear to have been substantial.

The decorated utility ware vessels from the Stallings site are dominated by sherds with incised decorative elements (Table 2 and Figure 3d-h, see also Figure 2b). All of these sherds, with the exception of three Coles Creek Incised rims, also appear to be part of an Early Caddo ceramic assemblage. These incised vessel sherds comprise 66 percent of the utility wares. Sherds with pinched-punctated rows 


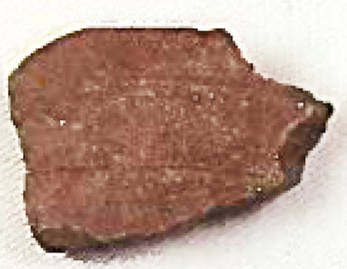

A

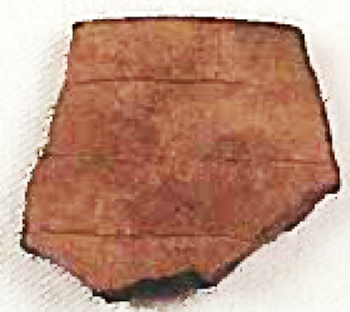

B

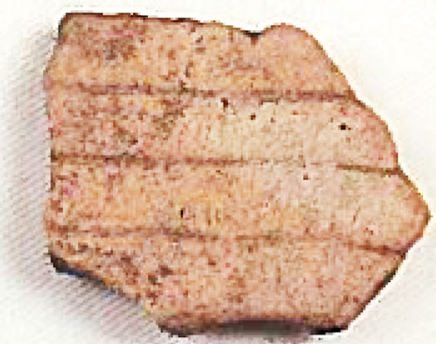

$\mathrm{C}$

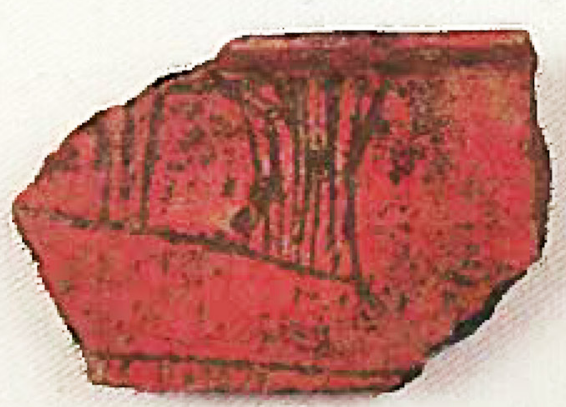

D

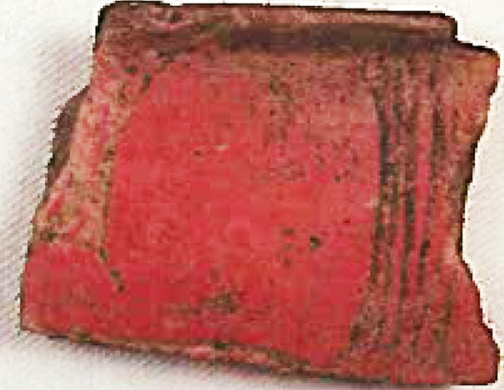

E

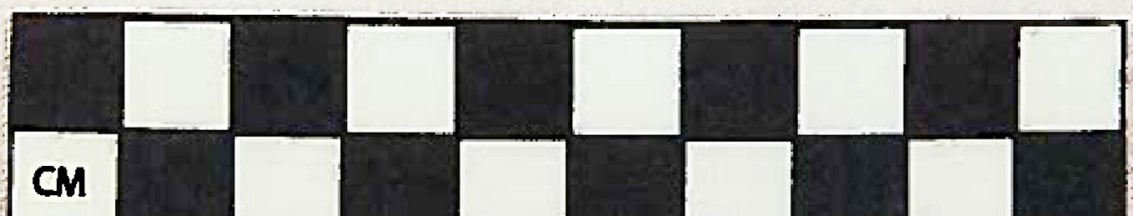

Figure 2. Fine ware and utility ware sherds from the Stallings site: a, curvilinear engraved lines on a body sherd, widely-spaced, Bottle; b, horizontal and diagonal incised rim; c, horizontal engraved rim; d-e, Clark Engraved rims from the same vessel. Provenience: a, Lot 2201; b, Lot 2071; c, Lot 1141 (N119 E220, lv. 5); d-e, Lot 1056 (N159 E210, lv. 4).

(Figures 3a and 4) account for another 16.4 percent, followed by sherds with incised-punctated (13.1 percent, Figure $3 \mathrm{~b}-\mathrm{c}$ ) decorative elements, and lastly tool, cane, and fingernail punctated (4.9 percent) body sherds.

Table 2. Utility ware sherd decorative elements from the Stallings site.

\begin{tabular}{lll}
\hline Decorative element & Rim sherd & Body sherd \\
\hline Vertical incised line & 1 & - \\
Single straight incised line & - & 10 \\
Parallel incised lines & - & 5 \\
Parallel incised lines, closely- & - & 6 \\
$\quad$ spaced & - & 1 \\
Diagonal incised lines, & - & 2 \\
widely-spaced & - & 4
\end{tabular}


Table 2. Utility ware sherd decorative elements from the Stallings site, cont.

\begin{tabular}{|c|c|c|}
\hline Decorative element & Rim sherd & Body sherd \\
\hline $\begin{array}{l}\text { Incised scroll el., Crockett } \\
\text { Curvilinear Incised }\end{array}$ & - & 4 \\
\hline Horizontal incised lines & 2 & - \\
\hline $\begin{array}{l}\text { Horizontal incised lines, with } \\
\text { incised lip line, Coles Creek } \\
\text { Incised }\end{array}$ & 3 & - \\
\hline $\begin{array}{l}\text { Horizontal and diagonal } \\
\text { incised lines }\end{array}$ & 2 & - \\
\hline $\begin{array}{l}\text { Straight incised lines and } \\
\text { triangular punctate zone }\end{array}$ & - & 1 \\
\hline $\begin{array}{l}\text { Straight incised lines and } \\
\text { tool punctate zone }\end{array}$ & - & 3 \\
\hline $\begin{array}{l}\text { Straight incised line and } \\
\text { cane punctated zone, } \\
\text { Crockett Curvilinear } \\
\text { Incised }\end{array}$ & - & 2 \\
\hline $\begin{array}{l}\text { Straight incised line and } \\
\text { circular punctated zone, } \\
\text { Crockett Curvilinear } \\
\text { Incised }\end{array}$ & - & 2 \\
\hline Fingernail punctated rows & - & 1 \\
\hline Cane punctated row & - & 1 \\
\hline Pinched-punctated rows & - & 10 \\
\hline Circular punctated, small & - & 1 \\
\hline Totals & 8 & 53 \\
\hline
\end{tabular}

The principal decorated type represented in the utility ware sherds from the Stallings site is Crockett Curvilinear Incised (Suhm and Jelks 1962), with eight sherds (see Table 2 and Figure 3e-f) from several different bowls; the two cane punctated and circular punctated body sherds may also be from this type (cf. Suhm and Jelks 1962:31). This is a well-known East Texas Caddo pottery type that was apparently widely manufactured between the ca. mid to late- $9^{\text {th }}$ century A.D and perhaps as late as ca. A.D. 1300 (Story 2000:14).

Four of these Crockett Curvilinear Incised sherds from the Stallings site have incised lines that are part of larger scroll elements and motifs (see Suhm and Jelks 1962:Plate 17b-c), while four others have incised zones (probably circles or curvilinear zones, see Suhm and Jelks 1962:Plate 17b, d) filled with small circular or cane punctations. Other sherds with incised decorative elements include straight, parallel, diagonal, or opposed lines (see Table 2), and these may be from other defined Early Caddo types, including Davis Incised, Dunkin Incised, or Kiam Incised.

There are three horizontal incised Coles Creek Incised sherds with incised lip lines or grooves (see Table 2 and Figure 3g-h). All three of these (Lots V49, 1140, and 2560) have a single horizontal incised line (but not overhanging) on the rim, and a lip line. Since the sherds are relatively small, it is not possible to suggest which variety of Coles Creek Incised may be represented in the Stallings site specimens because it is not known how many incised lines may have been on the rim or how widely they were spaced (cf. Brown 


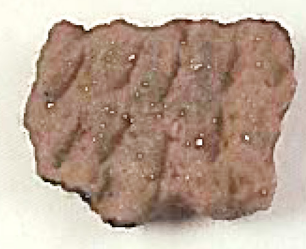

A

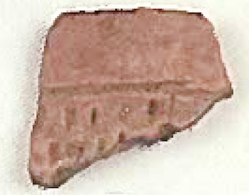

B

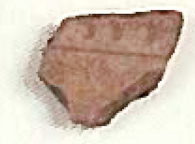

C

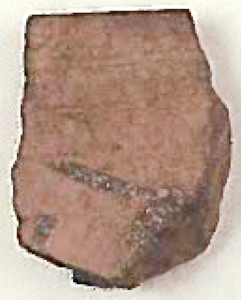

D

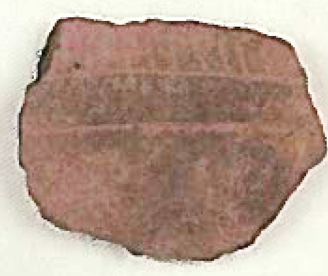

$E$
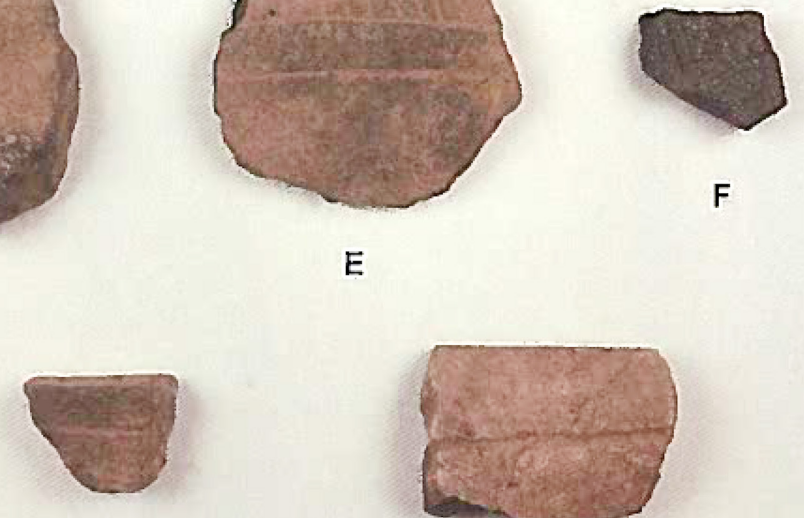

G

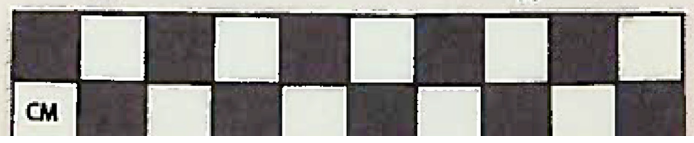

Figure 3. Decorated utility ware sherds from the Stallings site: a, pinched body sherd; $b$, incised and tool punctated-filled zone body sherd; c, Incised and cane-punctated-filled zone body sherd, Crockett Curvilinear Incised; d, horizontal and diagonal incised rim; e, incised scroll element, Crockett Curvilinear Incised, body sherd; f, incised scroll element, Crockett Curvilinear Incised, body sherd; g, Coles Creek Incised rim sherd; h, Coles Creek Incised rim. Provenience: a, Lot 1046 (N139 E230, lv. 2); b, Lot 2224 (N136 E225, lv. 5); c, Lot 1079 (N139 E240, lv. 2); d, Lot 2006; e, Lot 1309-3 (N109 E240, lv. 5); f, V84 (N165 E258, lv. 7); g, Lot 1140 (N129 E210, lv. 3); h, Lot 2560 (N139 E242, lv. 2).
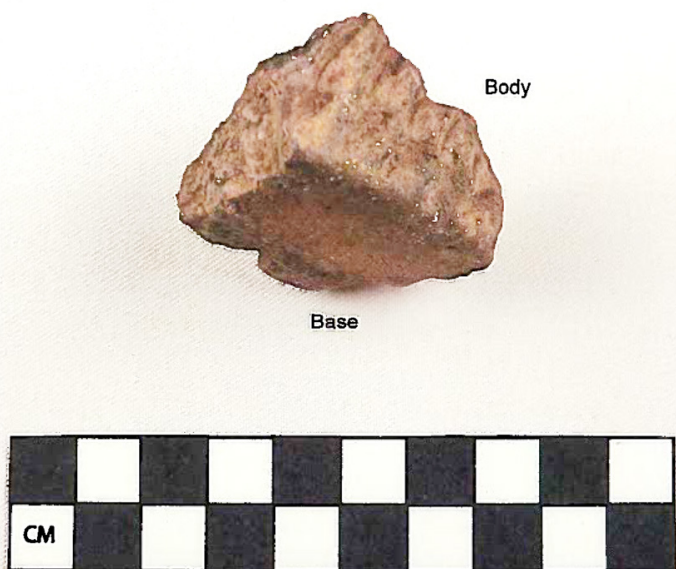

Figure 4. Vertical pinched body/base sherd, Lot 2440-2. 
1998:8). The most likely possibility, however, for all three Coles Creek Incised rims is var. Greenhouse, since this variety is grog-tempered, the incised lines are not overhanging, and the incised lines (two or three on the rim) are widely-spaced (see Figure 3h). According to Brown $(1998: 7,52)$, this variety of Coles Creek Incised was made in the lower Mississippi Valley from ca. A.D. 850-1000.

The pinched-punctated sherds (see Figures 3a and 4) have rows of pinching "made by pressing the thumb and index fingernails into the clay at the same time, with the fingernail impressions placed endto-end to form spiral lines or ridges" (Bruseth and Perttula 2006:85). Such pinched decorations were not present, apparently, in the slightly older Ray site ceramic assemblage (Bruseth et al. 2001:Table 8), but comprised 10 percent of the punctated sherds from the Early Caddo period ceramic vessel sherd sample at the Hudnall-Pirtle site (41RK4, see Bruseth and Perttula 2006:Table 2 and Figure 24a-b) on the Sabine River and were also present at the contemporaneous Boxed Springs (41UR30) mound center (Perttula and Wilson 2000:Figures 18, 22, and 24e and Table 2), also on the Sabine River. These are probably from Weches Fingernail Impressed vessels (see Suhm and Jelks 1962:Plate 77a, g, i).

The two horizontal-diagonal incised rim sherds (see Figures $2 \mathrm{~b}$ and $3 \mathrm{~d}$ ) may be from Dunkin Incised vessels (Suhm and Jelks 1962:Plate 19d). This identification is problematic without associated body sherds from the same vessels.

The fine ware vessel sherds from the Stallings site are thinner than the decorated utility ware or plain ware sherds (see below), particularly along the rim, but the body walls are almost 20 percent thinner on the fine wares than they are on the decorated utility wares (Table 3). For the rims, fine ware vessels are 20-30 percent thinner-walled than either the utility wares or the plain ware vessel rims.

Table 3. Thickness measurements for the decorated sherds.

\begin{tabular}{lll}
\hline Sherd Type & $\begin{array}{l}\text { Fine ware } \\
(\mathrm{mm})\end{array}$ & $\begin{array}{l}\text { Utility ware } \\
(\mathrm{mm})\end{array}$ \\
\hline rim & $4.98 \pm 0.83$ & $6.64 \pm 1.41$ \\
body & $5.56 \pm 0.90$ & $6.77 \pm 1.56$ \\
CV range & $16.2-16.6$ & $21.2-23.0$ \\
\hline
\end{tabular}

These variations in vessel wall thickness are likely related to functional and technological differences in how these different wares were intended to be used by Caddo potters. The more substantial vessel walls in the utility wares would be well suited to the cooking and heating of foods and liquids and would have contributed to their ability to withstand heat-related stresses. Fine wares were probably intended for use in the serving of foods and liquids.

Another factor that would influence vessel body wall thickness would be the sequence in which a vessel was constructed (Krause 2007:35). Vessels constructed from the bottom up, as these Early Caddo decorated vessels likely were, would tend to have thinner walls moving up the vessel body towards the rim, with the lower portion of the vessel-especially the base (not examined for this report)-usually significantly thicker than the upper portions of the vessel. 
Between 81.5-86.9 percent of the decorated sherds from the Stallings site had grog (crushed sherds) added to the clay paste (Table 4). Crushed and burned bone and crushed hematite, especially the former, were also added to the paste as temper in both wares, and occur in slightly higher but not statistically significant frequencies in the coarser utility wares. The few sherds from vessels with a sandy paste (apparently from the use of a naturally sandy clay) are restricted to the decorated utility wares.

Table 4. Temper inclusions in the decorated sherds from the Stallings site.

\begin{tabular}{|c|c|c|c|c|}
\hline \multirow[t]{2}{*}{ Temper/paste categories } & \multicolumn{2}{|c|}{ Fine ware } & \multicolumn{2}{|c|}{ Utility ware } \\
\hline & $\mathrm{N}$ & $\%$ & $\mathrm{~N}$ & $\%$ \\
\hline grog & 18 & 66.7 & 36 & 59.1 \\
\hline grog-bone & 4 & 14.8 & 12 & 19.7 \\
\hline bone & 3 & 11.1 & 7 & 11.5 \\
\hline bone-hematite & 1 & 3.7 & 1 & 1.6 \\
\hline bone-organics & 1 & 3.7 & - & - \\
\hline grog-organics & - & - & - & 1.6 \\
\hline grog-bone-hematite & - & - & 2 & 3.3 \\
\hline grog-sandy paste & - & - & 1 & 1.6 \\
\hline grog-bone-sandy paste & - & - & 1 & 1.6 \\
\hline$\%$ grog & & 81.5 & & 86.9 \\
\hline$\%$ bone & & 33.3 & & 37.7 \\
\hline$\%$ hematite & & 3.7 & & 4.9 \\
\hline$\%$ sandy paste & & 0.0 & & 3.2 \\
\hline Totals & 27 & 100.0 & 61 & 100.0 \\
\hline
\end{tabular}

Why did these potters use bone as a temper? In addition to it likely being a matter of personal preference or part of a family stylistic tradition for particular Fourche Maline or Caddo potters, the addition of coarse fragments of crushed bone (and hematite) would have made the clay more plastic and increased its strength and use-life, properties that were important in the successful manufacture of durable pottery vessels. Grog, on the other hand, contributes to the ability of the fired vessel to withstand heat-related stresses, as well as increasing its flexural strength. Such vessels would also have had better thermal conductivity (O'Brien et al. 1994:281; Rice 1987:362). These attributes suggest that the grogtempered decorated fine ware vessels (and the plain wares, see below) from the Stallings site were intended for long and common use, both for the cooking of food stuffs but also for serving hot and cold foods.

The Caddo fine ware and utility vessel sherds from the Stallings site were fired primarily in a reducing or low oxygen environment, probably smothering the vessel in a bed of coals from a wood fire (Table 5). This method of firing is typical of Caddo ceramic assemblages throughout East Texas, almost without exception. The percentage of fine ware sherds fired in a reducing environment is 88.9 percent, compared to 78.7 percent for the utility wares, and 77.8 percent for the plain rims (see below). 
Table 5. Firing Conditions in the decorated fine ware and utility ware sherds from the Stallings site.

\begin{tabular}{|c|c|c|c|c|}
\hline \multirow[t]{2}{*}{ Firing Condition* } & \multicolumn{2}{|c|}{ Fine ware } & \multicolumn{2}{|c|}{ Utility Ware } \\
\hline & $\mathrm{N}$ & $\%$ & $\mathrm{~N}$ & $\%$ \\
\hline Oxidizing Environment & 2 & 7.4 & 8 & 13.2 \\
\hline $\begin{array}{l}\text { Incompletely Oxidized } \\
\text { during Firing }\end{array}$ & 1 & 3.7 & 5 & 8.2 \\
\hline Reducing Environment & 8 & 29.6 & 16 & 26.2 \\
\hline $\begin{array}{l}\text { Reducing Environment, } \\
\text { and cooled in the } \\
\text { open air }\end{array}$ & 16 & 59.3 & 32 & 52.5 \\
\hline Totals & 27 & & 61 & \\
\hline
\end{tabular}

*Following Teltser (1993); Perttula (2005)

After firing, most of the vessels made and used at the Stallings site were apparently cooled in a high oxygen environment (52.5-59.3 percent), meaning that the fire-hardened vessels were probably removed from the fire to cool, producing a thin oxidized or lighter surface on either one or both vessel surfaces. The consistency in how the vessels at the site were fired indicates rather clearly that the Early Caddo potters who made those vessels were well-versed in regulating firing and cooling temperatures as well as maintaining control over the final finished end product, namely the manufacture of durable and relatively hard vessels with certain colors and hues.

Fine ware vessel sherds at the Stallings site are more frequently burnished (7-14 times more frequently) than the utility wares (Table 6), particularly on exterior vessel surfaces (22 percent). If not burnished, the fine wares tend to be well smoothed on the vessel exterior (51.9 percent); it is suspected that most of the fine wares were actually burnished after they were fired, but the burnish has been degraded by time and soil conditions. Utility ware sherds are from vessels that are commonly smoothed on one or both vessel surfaces (Table 6), with little difference between interior and exterior surfaces (21.3-24.6 percent). The frequency of utility ware vessels that have been smoothed on exterior surfaces (21.3 percent) suggests that not only were decorations on these vessels most likely restricted to rim or upper vessel areas (and left unsmoothed), but that the undecorated or lower portions of these vessels were sometimes smoothed before or after firing for some purpose.

Table 6. Surface treatment of the sample of ceramic vessel sherds from the Stallings Ranch site.

\begin{tabular}{|c|c|c|c|c|}
\hline \multirow[t]{2}{*}{ Surface Treatment } & \multicolumn{2}{|c|}{ Fine wares } & \multicolumn{2}{|c|}{ Utility wares } \\
\hline & $\mathrm{N}$ & $\%$ & $\mathrm{~N}$ & $\%$ \\
\hline Interior smoothing & 5 & 18.5 & 15 & 24.6 \\
\hline Exterior smoothing & 14 & 51.9 & 13 & 21.3 \\
\hline Interior burnishing & 3 & 11.1 & 1 & 1.6 \\
\hline Exterior burnishing & 6 & 22.2 & 1 & 1.6 \\
\hline Totals & 27 & & 61 & \\
\hline
\end{tabular}


The smoothing of utility ware interior vessel surfaces ( 24.6 percent) was probably done to lower the permeability and increase the heating effectiveness of particular vessels in cooking tasks (cf.

Rice 1996:148). With the fine wares, the well-smoothed and/or burnished interior surfaces may have been advantageous in the repeated use of these wares as food serving vessels. The purpose of exterior smoothing and burnishing (which are more common surface treatments in the fine wares) may have been for stylistic and display purposes, creating a flat and lustrous surface well-suited to highlight the engraved and/or slipped exterior surfaces of the fine ware vessels.

\section{The Plain Rim Sherds}

A total of 99 plain rim sherds have been recovered from the Stallings site excavations (Appendix 2). They have a variety of rim and lip forms (Figure 5a-c) as well as orifice diameters, suggesting they come from different sorts of vessels of wide-ranging sizes, although the rim sherds are in most cases too small to accurately determine the form of the vessel. Most appear to be from simple bowls and jars (cf. Bruseth et al. 2001:Figure 27a-e). Where measurable, vessel orifice diameters ranged from at least $11.0 \mathrm{~cm}$ to as large as $31.0 \mathrm{~cm}$ in size; the few decorated vessel rims with orifice diameter data had diameters that were larger than $10-12 \mathrm{~cm}$, but no more specific orifice diameter data could be determined.

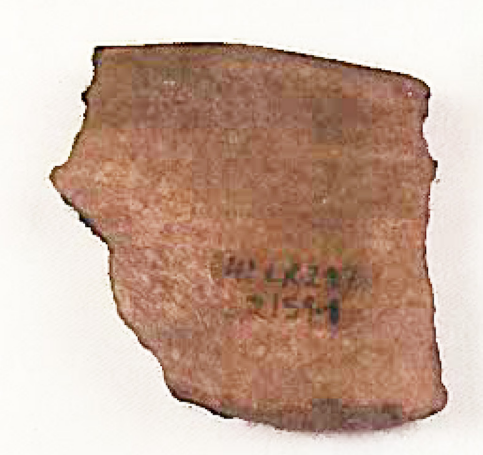

A
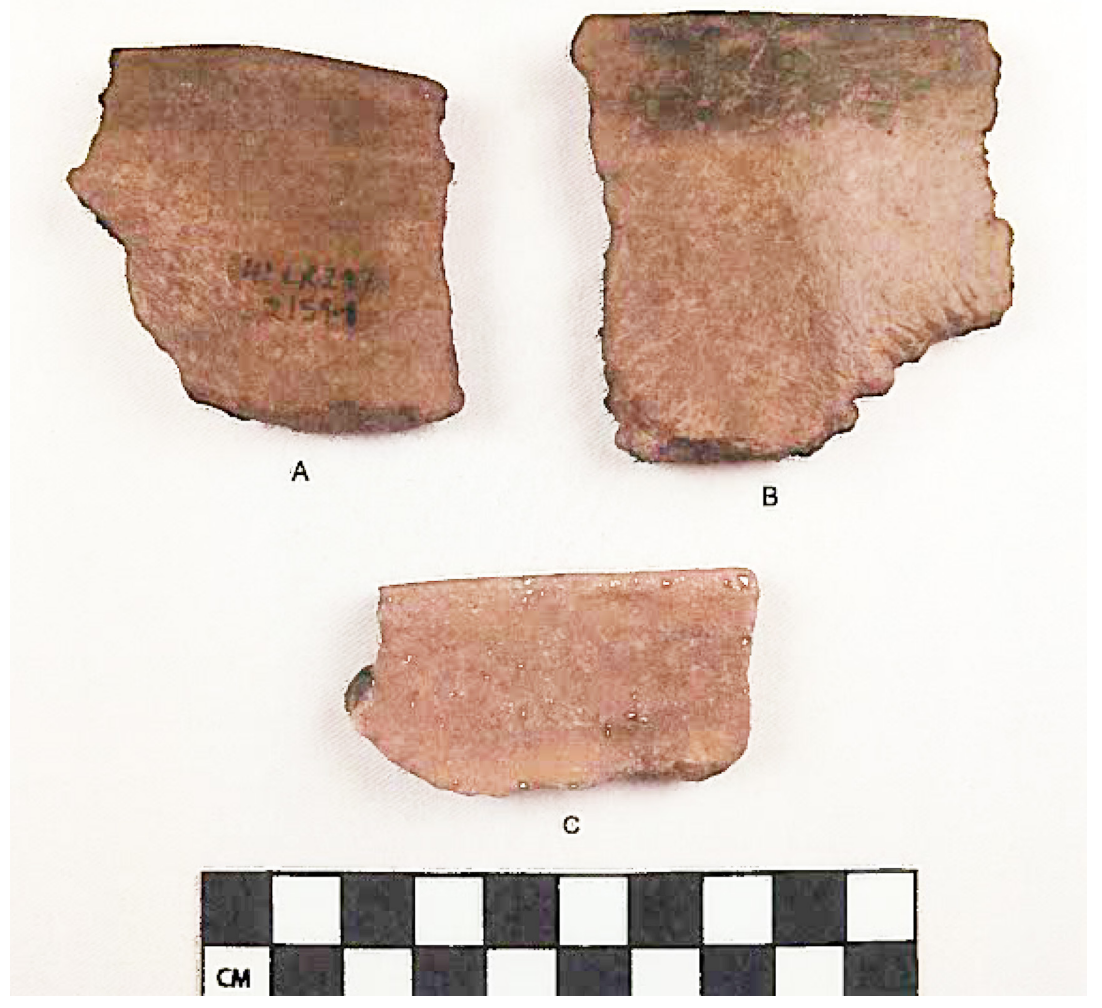

Figure 5. Selected plain rims from the Stallings site: a, direct rim-flat lip, grog-bone-tempered; b, direct rim-rounded lip, grog-tempered; c, direct rim-flat lip, bone-tempered. Provenience: a, Lot 2159 (N129 E221, lv. 4); b, Lot 2140 (N142 E236, lv. 3); c, Lot V76 (N145 E245, lv. 3).

Where this could be determined, about 90 percent of the plain rims $(n=65)$ have a direct or vertical rim profile (see Figure 5a-c); the four fine ware rims also have direct rims, as do 75 percent of the utility wares. Six rims (8 percent) have an everted profile and are probably from everted rim jars; two plain rims ( 3 percent) are from inverted rim bowls, as are two incised utility ware rims. Most of the vessels in turn have a rounded lip (73 percent) (see Figure 5b), with the remainder having flat lips ( 27 percent, see Figure 5a, c). Four of the plain rims have different and distinct lip treatments, two where the lip has been 
folded over to the exterior surface (as does the Clark Engraved rim, see Figure 2d-e), and two others in which the lip area is expanded or somewhat bulbous in profile.

Although these rims are plain and most of them are tempered with grog, I hesitate to classify them uniformly as Williams Plain, a plain and thick grog-tempered ware found on both Woodland Fourche Maline and Early Caddo period sites (cf. Bruseth et al. 2001; Schambach 1998). I do this in part because the rim sherds from the Stallings site are not necessarily very thick, the thickest rim sherds occur throughout the archaeological deposits (from lv. 1 to lv. 6) -in which Early Caddo decorated sherds also occur - and because the vessel forms that can be identified in the plain rims can be found in both Fourche Maline and Early Caddo ceramic assemblages. Perhaps the only way to accurately separate plain grogtempered rim sherds from a site such as the Stallings site would have been to submit multiple rim sherds for thermoluminescence dating, and based on the results, independently determine if there are certain attributes of the rims that are temporally sensitive beyond a simple thickness measurement.

The plain rims from the Stallings site have a mean thickness of $6.90 \pm 1.05 \mathrm{~mm}$, with a range of 4.1-11.0 mm. At one standard deviation, the mean thickness of the plain rims is $5.85-7.95 \mathrm{~mm}$. Almost three-fourths of the plain rims are less than $8.0 \mathrm{~mm}$ in thickness, and only 6 percent are more than 9.0 $\mathrm{mm}$ in thickness. In samples of Williams Plain sherds discussed by Schambach (1998:22) and Bruseth et al. (2001), thickness measurements are provided for body and base sherds only, and thus it is impossible to compare the Stallings site rim thickness to the thickness of the plain rims in larger sherd assemblages with Fourche Maline affiliations. Overall, however, the mean thickness of the rims is consistent with the Early Caddo ceramic vessel sherds from the Roitsch site (Skinner et al. 1969:Table 7).

About 20 percent of the plain rims have some form of surface treatment. This includes interior (21.2 percent) and exterior (19.2 percent) smoothed surfaces and interior (1 percent) and exterior ( 1 percent) burnishing. These proportions of interior and exterior smoothing and burnishing on the plain rims are closely comparable to that noted for the utility wares (see Table 6), suggesting the two pottery wares may have been used for the same purposes.

The plain rims from the Stallings site are tempered primarily with grog or crushed sherds, as almost 95 percent of the sherds have grog added to the paste, either as the sole temper, or in combination with crushed bone, hematite, or charred organic materials (Table 7). The use of grog temper in the plain wares is about 10 percent higher than in either the fine wares or utility wares (see Table 4).

Table 7. Temper inclusions in the plain rim sherds from the Stallings Ranch site.

\begin{tabular}{lll}
\hline Temper/paste categories & $\mathrm{N}$ & Percent \\
\hline grog & 58 & 58.6 \\
grog-bone & 20 & 20.2 \\
grog-hematite & 6 & 6.1 \\
grog-organics & 5 & 5.1 \\
grog/sandy paste & 3 & 3.0 \\
bone & 3 & 3.0 \\
grog-bone-hematite & 2 & 2.0 \\
bone-hematite & 2 & 2.0 \\
& & 94.9 \\
$\%$ with grog & & 27.2 \\
$\%$ with bone & & 10.1 \\
\hline with hematite & & 100.0 \\
\hline Totals & 99 & \\
\hline
\end{tabular}


Slightly more than 27 percent of the plain rims have burned bone temper (mostly in combination with grog), another 10 percent have pieces of crushed hematite (again, mostly with grog temper), and 5 percent have charred organics in the paste (always in combination with grog temper) that was not completely combusted when the vessel was fired (see Table 7). The proportion of bone temper use is quite comparable to that seen at the Ray site (41LR135), where bone or grog-bone-tempered sherds account for between 26-30.7 percent of the assemblage (Bruseth et al. 2001).

The plain rims are from vessels that were fired most regularly in a low oxygen or reducing environment, probably by nestling the vessels amidst the coals during the firing (Table 8). In turn, most of these vessels were pulled from the fire to cool in the open air, leaving them with either lighter-colored interior or exterior oxidized surfaces. Sherds from these particular vessels account for 57.6 percent of all the plain rims.

Table 8. Firing Conditions in the Plain Rim Sherds from the Stallings Ranch site.

\begin{tabular}{lcc}
\hline Firing Condition* & $\mathrm{N}$ & Percent \\
\hline $\begin{array}{l}\text { Oxidizing Environment } \\
\begin{array}{l}\text { Incompletely Oxidized } \\
\text { during firing }\end{array}\end{array}$ & 13 & 13.1 \\
$\begin{array}{l}\text { Reducing Environment } \\
\text { Reducing Environment, but } \\
\text { cooled in the open air }\end{array}$ & 9 & 9.1 \\
\hline
\end{tabular}

*after Teltser (1993)

\section{Long-stemmed Clay Pipe Sherds}

The 67 long-stemmed clay pipe sherds (see Appendix 3) from the Stallings site are from Red River style pipes (see Hoffman 1967). The quantity of long-stemmed pipe sherds is impressive given the size of the vessel sherd assemblage (i.e., ratio of ceramic vessel sherds to pipe sherds is 20:1), suggesting that pipe manufacture and smoking were important activities of the Stallings site occupants. By way of comparison, at the Ray site, the vessel sherd to pipe sherd ratio is 55:1 (Bruseth et al. 2001:7), and in Bruseth et al.'s (2009) excavations at the Stallings site, the ratio is 126:1, but that ratio increases to more than 1000:1 in post-A.D. 1300 McCurtain phase contexts at the Roitsch site (41RR16) in Red River County, Texas (Perttula et al. 2001:182-183 and Table 3).

This style of pipe has several temporally distinct varieties based on differences in stem shape and stem thickness, but Hoffman's (1967) analysis - as well as excavations conducted since his work in the Caddo area - has shown that Red River long-stemmed pipes with small delicate bowls were made by late Fourche Maline and Caddo groups from the early $9^{\text {th }}$ century A.D. to the early $15^{\text {th }}$ century A.D., eventually being replaced by several kinds of clay elbow pipes. None of these long-stemmed pipes were designed to hold large amounts of smoking material, and Hoffman (1967:9) describes the bowls as "thimble-sized," whether that was tobacco or some other smoking concoction.

There are 11 pipe bowl sherds and 56 pipe stem sherds in the Stallings site assemblage. The bowl sherds are thin (mean thickness of $2.31 \mathrm{~mm}$ ), with a mean orifice diameter of $31.97 \mathrm{~mm}$. In one instance, the bowl height of one pipe could be estimated as at least $16.2 \mathrm{~mm}$ (Figure 6e).

With respect to the pipe stems, six sherds have a blunt and flat end on the distal side of the pipe bowl (see Figure 6c) opposite the stem opening, four others are stem sherds that have evidence of the lower 
bowl attachment (see Figure 6d), and the other 46 sherds are fragments of the long stem (see Figure $6 a-b)$. The stems of these pipes are also thin, with a mean average of $1.38 \mathrm{~mm}$. They also have narrow stem openings with which to draw the smoke, with mean exterior stem diameters of $7.39 \mathrm{~mm}$ and mean interior stem diameters or interior holes of $2.65 \mathrm{~mm}$.

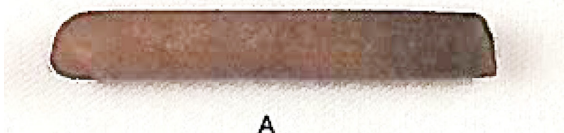

A
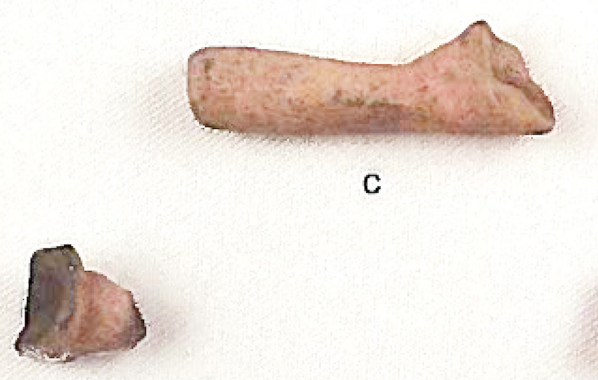

D

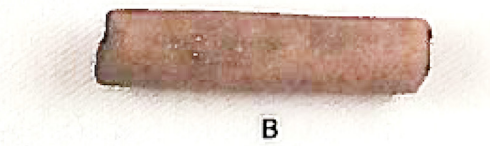

B

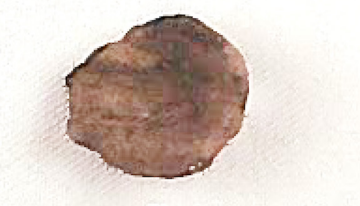

E

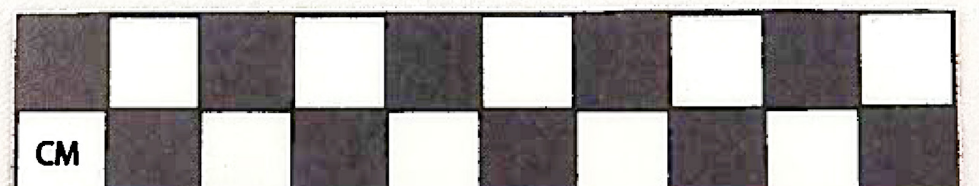

Figure 6. Pipe sherds from the Stallings site: a-b, pipe stems; c, blunt end of a pipe stem and the lower bowl attachment; d, stem and lower bowl attachment; e, pipe bowl. Provenience: a-b, Lot V94 (no provenience); c, Lot 1432-1 (N109 E240, lv. 6); d, Lot 1129 (N134 E224, lv. 3); e, Lot 1491 (N136 E234 profile).

The very small stem diameters of the pipe sherds, as well as the small stem hole diameters, very thin walls and small bowl, and the blunt distal stem projections of the Stallings site long-stemmed pipe sherds are from the Miller's Crossing variety of the Red River pipe (Hoffman 1967:9). This variety of longstemmed pipe, also common at the Ray site (Bruseth et al. 2001), is apparently the earliest Caddo style of long-stemmed pipe found in Northeast Texas. Hoffman (1967:9) speculates that this variety of Red River pipe may date to ca. A.D. 900-1000, but it probably was made until at least ca. A.D. 1100 to A.D. 1200 based on its recovery at a number of other Early Caddo sites in the region.

The long-stemmed Red River pipes from the Stallings site are primarily tempered with very finelycrushed and burned bone (67.2 percent), with lesser numbers tempered with finely crushed grog (29.9 percent) or tempered with a combination of bone and grog (1.5 percent). One pipe sherd came from a pipe with no visible temper.

The pipes were fired rather uniformly in a low oxygen or reducing environment ( 80.6 percent), about equally divided between those pipes allowed by the pipe makers to cool in that same kind of low oxygen environment (i.e., nestled in the coals) - producing a dark gray to black surface color (34.3 percent)and those that were removed from the fire to cool in the open air (46.3 percent). These latter pipes then had at least one surface with a thin oxidized or lighter color, usually on the exterior of the pipe itself. The remainder of the pipes (19.4 percent) were fired and cooled in a high oxygen environment, creating longstemmed pipes that were brown in color throughout. 


\section{Discussion of the Ceramic Assemblage from the Stallings Ranch Site}

If the Stallings Ranch site ceramic vessel sherds were to be considered to represent a single homogeneous prehistoric assemblage - which there is not necessarily any reason to do given the apparent widespread distribution of both Woodland and Caddo period diagnostics in the excavations (S. Alan Skinner, 2007 personal communication) as well as the identification of putative Fourche Maline and Caddo post holes (Skinner 2007: Figure 1, Skinner 2016) across the site -it would be readily interpreted as an Early Caddo ceramic assemblage. This would be based on the following: (a) heavy use of grog-tempered pottery; (b) occurrence of sherds from Early Caddo ceramic types, including Crockett Curvilinear Incised, Dunkin Incised, Weches Fingernail Impressed, Holly Fine Engraved, and Hickory Engraved, as well as the presence of engraved fine wares, a notable post-A.D. 900 Caddo decorative method; (c) the manufacture and use of Red River style, Miller's Crossing variety long-stemmed pipes; and (d) the generally thin rim and body walls of both the plain and decorated wares from the site.

A distinctive feature of the Stallings site ceramic assemblage from the TAS work is the abundance of plain vessels, as seen in the many plain rims $(n=99)$ and a P/DR value of 14.3:1. Some of the plain rims may be identified as Williams Plain because of their great thickness (greater than 9.0-11.0 mm, see Appendix 2); at the ca. A.D. 550-850 Woodland period Fourche Maline occupation at the Snipes site (41CS8) on the Sulphur River, Williams Plain rims range from 8.2-10.8 $\mathrm{mm}$ in thickness (Sitters and Perttula 2017:Table 4). Williams Plain sherds are present in some considerable numbers at the Ray site (Bruseth et al. 2001:200), but account for only 3 percent of the plain sherds from the East Mound excavations at the Sam Kaufman site.

Table 9. Other Early Caddo Ceramic Assemblages in Northeast Texas.

\begin{tabular}{llll}
\hline Assemblage Attributes & & Sites & \\
& Ray & Sam Kaufman* & Hudnall-Pirtle \\
\hline Decorated sherds & 101 & 163 & 681 \\
Plain sherds & 5719 & 792 & 2735 \\
P/DR & $56.6: 1$ & $48.6: 1$ & $4.02: 1$ \\
& & & 71 \\
Grog temper \% & 73 & 94 & 12 \\
Bone temper \% & 27 & 6 & 222 \\
Incised sherds & 83 & 63 & 24 \\
Punctated sherds & 14 & 19 & - \\
Incised-punctated sherds & - & 2 & 149 \\
Brushed sherds & 3 & - & - \\
Engraved sherds & 1 & 1 & + \\
Red-slipped & - & 70 & + \\
Coles Creek Incised & + & + & + \\
Crockett Curvilinear Incised & + & + & \\
French Fork Incised & + & + & \\
Hickory/Holly Engraved & & & \\
Williams Plain & + & & \\
\hline
\end{tabular}

*East Mound (Skinner et al. 1969:Tables 5 and 6) 
Other generally contemporaneous sites in the same region as Stallings, including Ray (41LR135) and Sam Kaufman (41RR16) also have plain ware-dominated ceramic assemblages (Bruseth et al. 2001; Skinner et al. 1969). Conversely, the Hudnall-Pirtle site (41RK4), on the Sabine River, Early Caddo ceramic assemblage is not as strongly plain ware-dominated, and is apparently the product of a different Caddo pottery tradition (see Table 9). At the Ray site, which has nine calibrated radiocarbon dates that range from A.D. 700-1200 (Bruseth et al. 2001:Table 11) - with six that postdate A.D. 1000the P/DR value is 56.6:1. Excavations at the East Mound at Sam Kaufman recovered an Early Caddo ceramic assemblage from archaeological deposits (House 3) with four calibrated dates: their mean age ranges from A.D. 1008-1206 (Perttula 1998:334). The P/DR of this assemblage is 48.6:1 (see Table 9). It is clearly evident then that the Red River-dated Caddo assemblages occupied before ca. A.D. 1200 are dominated by plain wares, mostly Williams Plain at the Ray site (Bruseth et al. 2001:200) and unspecified and not particularly thick plain wares from the East Mound excavations at Sam Kaufman and the Stallings site. Interestingly, the Stallings site P/DR value from the TAS excavations lies closer to that from the Hudnall-Pirtle site than it does to the Red River Early Caddo ceramic assemblages, although it is doubtful there is any specific Caddo affiliations between these two sites.

With respect to the different kinds of decorated sherds found in Early Caddo assemblages, incised decorative elements predominate in each (see Table 9), just as they do at the Stallings site. These incised vessels have primarily simple straight line and geometric designs, with a number of horizontally incised rims, including rims from Coles Creek Incised vessels along with Caddo types such as Davis Incised, Dunkin Incised, and Kiam Incised. Incised and incised-punctated elements from Crockett Curvilinear Incised vessels are also important constituents of these Early Caddo ceramic assemblages. Locally, examples of French Fork Incised (made between ca. A.D. 700-1000 in the lower Mississippi Valley, see Brown 1998:54-55) are present in limited amounts on the Red River sites: five sherds each from the Ray and Sam Kaufman sites (Bruseth et al. 2001; Skinner et al. 1969).

It is notable that engraved pottery is virtually nil in the Early Caddo ceramic assemblages from the Ray and Sam Kaufman sites (see Table 9), even in occupations that date as late as ca. A.D. 1200, as do the archaeological deposits associated with much of the Caddo occupation at the East Mound at the Sam Kaufman site (see Regnier 2017:188-189). At the contemporaneous Hudnall-Pirtle site, however, 22 percent of the decorated sherds have engraved designs, as do 30 percent of the decorated sherds from the Stallings site (see Table 9). These appear to be from Hickory Engraved and Holly Fine Engraved vessels. This substantial discrepancy in the proportions of engraved fine wares between generally contemporaneous Early Caddo sites warrants an explanation that is not founded on temporal differences. Perhaps personal, social, or community preferences were a factor in decisions about what kinds of ceramic vessels were made and used for serving foods and liquids by different Early Caddo groups, and on the Red River in some settings, it was not until after ca. A.D. 1200 that engraved fine wares became an important constituent of both domestic and civic-ceremonial ceramic assemblages.

Another shared characteristic of these Early Caddo ceramic assemblages and the Stallings site ceramics is that they are predominantly grog-tempered (see Table 9). There is a modicum of use of crushed and burned bone as a temper, more so at Stallings and the Ray site than at either the Sam Kaufman and Hudnall-Pirtle sites, but there is some considerable diversity in temper selection and use suggesting the existence of a number of small scale and localized ceramic traditions in pre-A.D. 1200 contexts between the Red and Sabine river basins in East Texas.

\section{Summary}

During the course of Texas Archeological Society Field Schools in 2005 and 2006, and earlier work by the Valley of the Caddo Archeological Society, a small assemblage of decorated sherds, plain rims, and long-stemmed pipe sherds were recovered from the Gene and Ruth Ann Stallings Ranch site (41LR297). Analysis of these ceramic artifacts - particularly the decorated fine wares and utility 
wares and the Red River style, Miller's Crossing variety pipes - indicate that they are primarily, if not necessarily exclusively, the product of a pre-A.D. 1150 Early Caddo occupation at the site. One engraved rim is from a transitory post-A.D. 1300 Caddo use. The dominance of plain rims $(n=99)$ to decorated vessel rims $(n=12)$ is compelling evidence that most of the vessels in use at the site were undecorated.

Among the decorated sherds, however, 30 percent are from engraved fine wares (including Hickory Engraved, Holly Engraved, and Clark Engraved). The remaining 70 percent are utility wares decorated with incised, incised-punctated, pinched, and punctated elements. Crockett Curvilinear Incised is well represented in the utility wares as is Weches Fingernail Impressed. In general, the fine ware and utility ware decorative elements have uncomplicated straight line, geometric, and curvilinear emphases and orientations. Three of the rims are from grog-tempered Coles Creek Incised vessels.

These sherds are primarily from grog-tempered vessels of no particular or noteworthy thickness, which would have been expected if there was a substantial Woodland or Fourche Maline occupation. There is a significant use of burned bone for temper among all three wares. The long-stemmed Miller's Crossing variety pipes from the Stallings site, as is usual for this class of artifacts in East Texas, Southwest Arkansas, and Northwest Louisiana Caddo sites, are overwhelmingly tempered with finely crushed bone (Hoffman 1967:9). Both the vessels and long-stemmed pipes had been mainly fired in a reducing or low oxygen environment

The occurrence of many plain rims at the Stallings site, some of which are rather thick, does suggest, however, that some of these plain rim sherds are likely from a Woodland period Fourche Maline Culture occupation. The overall thickness of many of the plain rim sherds when compared to the thickness of the decorated wares also indicates that similar sorts of plain vessels were made and used in Early Caddo times at the site as well. On their own merits (i.e., grog and grog-bone-tempered, of variable thicknesses, and occurring at variable depths in the archaeological deposits), it is currently not possible to sort Fourche Maline from Early Caddo plain rims at the Stallings site (and this is probably the case at many other sites as well in the middle Red River basin). Without being able to accomplish this basic sorting, it is difficult without expanding dating efforts and completing detailed rim attribute studies keyed to chronologically discrete occupational deposits, to assess the relative contribution in the plain wares of either the Woodland and Early Caddo periods ceramic sets. Certainly the decorated vessel sherds are from the Caddo settlement of this place, which took place before ca. A.D. 1150/1200. The relatively high frequency of engraved sherds (30 percent) in the decorated sherds from the Stallings site is regionally and temporally distinctive since other sites in the Red River basin of generally contemporaneous ageincluding Ray (41LR135) and Sam Kaufman/Roitsch (41RR16) - have few engraved sherds from habitation contexts.

\section{Acknowledgements}

I appreciate the opportunity afforded by S. Alan Skinner to analyze this portion of the prehistoric ceramics from the Stallings site, which was completed in 2008.

\section{References Cited}

Brown, I. W.

1998 Decorated Pottery of the Lower Mississippi Valley: A Sorting Manual. Mississippi Archaeological Association and Mississippi Department of Archives and History, Jackson.

Brown, J. A.

1996 The Spiro Ceremonial Center: The Archaeology of Arkansas Valley Caddoan Culture in Eastern Oklahoma. Memoirs No. 29. Museum of Anthropology, University of Michigan, Ann Arbor. 
Bruseth, J. E. and T. K. Perttula, with contributions by G. J. Fritz and B. C. Yates

2006 Archeological Investigations at the Hudnall-Pirtle Site (41RK4): An Early Caddo Mound Center in Northeast Texas. Caddo Archeology Journal 15:57-158.

Bruseth, J. E., L. Banks, and J. Smith

2001 The Ray Site (41LR135). Bulletin of the Texas Archeological Society 72:197-213.

Bruseth, J. E., J. Durst, R. Proctor, L. Banks, G. Sykes, and B. Pierson

2009 Investigations at the Gene and Ruth Stallings Ranch Site (41LR297). Bulletin of the Texas Archeological Society 80:195-205.

Diggs, G. M., Jr., B. L. Lipscomb, M. D. Reed, and R. J. O'Kennon

2006 Illustrated Flora of East Texas. Volume One: Introduction, Pteridophytes, Gymnosperms, and Monocotyledons. Botanical Research Institute of Texas, Fort Worth.

Hoffman, M. P.

1967 Ceramic Pipe Style Chronology Along the Red River Drainage in Southwestern Arkansas. The Arkansas Archeologist 8(1):4-14.

Krause, R.A.

2007 A Potter's Tale. In Plains Village Archaeology: Bison-hunting Farmers in the Central and Northern Plains, edited by S. A. Ahler and M. Kay, pp. 32-40. University of Utah Press, Salt Lake City.

O’Brien, M. J., T. D. Holland, R. J. Hoard, and G. L. Fox

1994 Evolutionary Implications of Design and Performance Characteristics of Prehistoric Pottery. Journal of Archaeological Method and Theory 1:259-304.

Perino, G., with contributions by L. Blake and C. J. Loveland

1994 The Rowland Clark (41RR77) Site, Red River County, Texas. Journal of Northeast Texas Archaeology 4:3-60.

Perttula, T. K.

1998 A Compendium of Radiocarbon and Oxidizable Carbon Ratio Dates from Archaeological Sites in East Texas, with a Discussion of the Age and Dating of Select Components and Phases. Radiocarbon 39(3):305-341.

2004 The Prehistoric and Caddoan Archeology of the Northeastern Texas Pineywoods. In The Prehistory of Texas, edited by T. K. Perttula, pp. 370-407. Texas A\&M University Press, College Station.

Perttula, T. K. (editor)

2005 Archeological Investigations at the Pilgrim's Pride Site (41CP304), a Titus Phase Community in the Big Cypress Creek Basin, Camp County, Texas. 2 Vols. Report of Investigations No. 30. Archeological \& Environmental Consultants, LLC, Austin.

2008 The Archeology of the Roitsch Site (41RR16), an Early to Historic Caddo Period Village on the Red River in Northeast Texas. In Collected Papers from Past Texas Archeological Society Summer Field Schools, edited by T. K. Perttula. Special Publication No. 5. Texas Archeological Society, in press.

Perttula, T. K. and D. E. Wilson, with contributions by M. Walters

2000 An Early Caddoan Period Cremation from the Boxed Springs Mound Site (41UR30) in Upshur County, Texas, and a Report on Previous Archaeological Investigations. Journal of Northeast Texas Archaeology 12:31-71. 
Perttula, T. K., J. E. Bruseth, N. A. Kenmotsu, D. J. Prikryl, W. A. Martin, L. Banks, J. Smith, N. G. Reese, and S. A. Iruegas

2001 Archeological Investigations on the Red River and Tributaries: Summary of the Findings of the 1991 and 1992 Texas Archeological Society Field School in Red River and Lamar Counties, Texas. Bulletin of the Texas Archeological Society 72:165-250.

Perttula, T. K., M. R. Miller, R. A. Ricklis, D. J. Prikryl, and C. Lintz

1995 Prehistoric and Historic Aboriginal Ceramics in Texas. Bulletin of the Texas Archeological Society 66:175-235.

Perttula, T. K., M. Walters, and B. Nelson

2016 Caddo Ceramic Vessels from the T. M. Sanders Site (41LR2) on the Red River in Lamar County, Texas. Special Publication No. 41. Friends of Northeast Texas Archaeology, Austin and Pittsburg.

Prikryl, D. J.

2008 The 1991 and 1992 Texas Archeological Society Field School Excavations at the Fasken Site (41RR14), Red River County, Texas. In Collected Papers from Past Texas Archeological Society Summer Field Schools, edited by T. K. Perttula. Special Publication No. 5. Texas Archeological Society, San Antonio.

Regnier, A.

2017 The Relationship between Becoming Caddo and Becoming Mississippian in the Middle Red River Drainage. In Mississippian Beginnings, edited by G. D. Wilson, pp. 178-202. University of Alabama Press, Tuscaloosa.

Rice, P. M.

1987 Pottery Analysis: A Sourcebook. University of Chicago Press, Chicago.

1996 Recent Ceramic Analysis: 1. Function, Style, and Origins. Journal of Archaeological Research 4(2):133-163.

Schambach, F. F.

1998 Pre-Caddoan Cultures in the Trans-Mississippi South: A Beginning Sequence. Research Series 53. Arkansas Archeological Survey, Fayetteville.

Schambach, F. F. and J. E. Miller

1984 A Description and Analysis of the Ceramics. In Cedar Grove: An Interdisciplinary Investigation of a Late Caddo Farmstead in the Red River Valley, edited by N. L. Trubowitz, pp. 109-170. Research Series No. 23. Arkansas Archeological Survey, Fayetteville.

Sitters, J. A. and T. K. Perttula

2017 Another Look at the Snipes Site (41CS8) on the Sulphur River, Cass County, Texas. Journal of Northeast Texas Archaeology 75:53-77.

Skinner, S. A.

2007 An Update on the Gene and Ruth Ann Stallings Site \& A Plea for Your Help. Texas Archeology 51(1):13.

Skinner, S. A. (editor)

2016 Archaeological Investigations at the Gene and Ruth Ann Stallings Ranch, Lamar County, Texas. Draft MS on file, Texas Archeological Society, San Antonio. 
Skinner, S. A., R. K. Harris, and K. M. Anderson (editors)

1969 Archaeological Investigations at the Sam Kaufman Site, Red River County, Texas. Contributions in Anthropology No. 5. Southern Methodist University, Dallas.

Story, D. A.

2000 Introduction. In The George C. Davis Site, Cherokee County, Texas, by H. P. Newell and A. D. Krieger, pp. 1-31. $2^{\text {nd }}$ Edition. Memoirs No. 5. Society for American Archaeology, Washington, D.C.

Suhm, D. A. and E. B. Jelks (editors)

1962 Handbook of Texas Archeology: Type Descriptions. Special Publication No. 1, Texas Archeological Society, and Bulletin No. 4, Texas Memorial Museum, Austin.

Teltser, P. A.

1993 An Analytic Strategy for Studying Assemblage-Scale Ceramic Variation: A Case Study from Southeast Missouri. American Antiquity 58(3):530-543. 


\section{Appendix 1,}

\section{Detailed Analysis of Decorated Sherds from the Stallings Site}

\begin{tabular}{|c|c|c|c|c|c|c|c|}
\hline Lot No. & Sherd type & Temper & $\mathrm{FC}$ & ST & $\begin{array}{l}\text { Th } \\
(\mathrm{mm})\end{array}$ & Decoration & Comments \\
\hline 1004 & body & $b-g$ & E & - & 11.5 & rectilinear incised lines & \\
\hline 1006 & body & $\mathrm{g}$ & $\mathrm{F}$ & I SM & 5.5 & $\begin{array}{l}\text { parallel incised lines } \\
\text { and small tool punctate- } \\
\text { filled zone }\end{array}$ & $\begin{array}{l}\text { cf. Crockett- } \\
\text { Pennington }\end{array}$ \\
\hline $1016-3$ & rim (INV-Ro) & $\mathrm{b}$ & $\mathrm{F}$ & - & 8.0 & $\begin{array}{l}\text { single vertical incised } \\
\text { line }\end{array}$ & $\mathrm{OD}=10+\mathrm{cm}$ \\
\hline 1037 & body & $g-b$ & G & - & 4.0 & $\begin{array}{l}\text { single straight engraved } \\
\text { line }\end{array}$ & \\
\hline 1046 & body & $g-b$ & $\mathrm{H}$ & - & 8.8 & $4+$ pinched rows & \\
\hline 1056 & $\operatorname{rim}(\mathrm{D}-\mathrm{Ro}$, ext f) & $\mathrm{g}$ & $\mathrm{B}$ & $\mathrm{I} / \mathrm{E} \mathrm{B}$ & 5.8 & $\begin{array}{l}\text { engraved scrolls; red- } \\
\text { slipped }\end{array}$ & $\begin{array}{l}\text { Clark } \\
\text { Engraved }\end{array}$ \\
\hline 1072 & body & g & $\mathrm{K}$ & - & 6.8 & $\begin{array}{l}\text { single straight incised } \\
\text { line }\end{array}$ & \\
\hline 1079 & body & g & $\mathrm{G}$ & E SM & 4.8 & $\begin{array}{l}\text { straight incised line and } \\
\text { cane punctated row }\end{array}$ & $\begin{array}{l}\text { Crockett } \\
\text { Curvilinear } \\
\text { Incised }\end{array}$ \\
\hline 1094-1 & body & $b-h$ & $\mathrm{H}$ & - & 8.9 & $\begin{array}{l}\text { deep fingernail punctated } \\
\text { rows }\end{array}$ & \\
\hline 1117 & body & $g-b$ & G & I/E SM & 3.9 & $\begin{array}{l}\text { incised zone filled with } \\
\text { triangular tool punctates }\end{array}$ & \\
\hline 1125 & body & $\mathrm{g}$ & $\mathrm{H}$ & E SM & 6.4 & $\begin{array}{l}\text { single straight incised } \\
\text { line }\end{array}$ & \\
\hline 1140 & $\operatorname{rim}(\mathrm{D}-\mathrm{FL})$ & $g-b$ & $\mathrm{~B}$ & E SM & 8.0 & $\begin{array}{l}\text { single horizontal } \\
\text { incised line; incised } \\
\text { lip line }\end{array}$ & $\begin{array}{l}\text { Coles Creek } \\
\text { Incised }\end{array}$ \\
\hline 1141 & $\operatorname{rim}(\mathrm{D}-\mathrm{FL})$ & g & $\mathrm{F}$ & - & 5.8 & $\begin{array}{l}4+\text { horizontal engraved } \\
\text { lines }\end{array}$ & $\mathrm{OD}=11+\mathrm{cm}$ \\
\hline 1193 & body & $g-b$ & $\mathrm{~F}$ & - & 8.1 & $1+$ pinched row & \\
\hline 1205 & body & g-b-h & $\mathrm{E}$ & - & 8.1 & $2+$ pinched rows & \\
\hline 1217 & body & $\mathrm{g}$ & A & - & 8.0 & $\begin{array}{l}2+\text { parallel incised lines, } \\
\text { closely-spaced }\end{array}$ & \\
\hline $1309-3$ & body & g & $\mathrm{B}$ & E SM & 5.1 & incised scroll el. & $\begin{array}{l}\text { Crockett } \\
\text { Curvilinear } \\
\text { Incised }\end{array}$ \\
\hline 1364 & body & g & A & - & 5.6 & $\begin{array}{l}\text { single straight engraved } \\
\text { line }\end{array}$ & \\
\hline 1372 & body & $\mathrm{b}$ & $\mathrm{E}$ & - & 7.9 & $2+$ pinched rows & \\
\hline $1418-2$ & body & $\mathrm{g}$ & $\mathrm{G}$ & $\mathrm{I} / \mathrm{E} \mathrm{B}$ & 4.0 & $\begin{array}{l}3+\text { parallel engraved lines, } \\
\text { widely-spaced }\end{array}$ & \\
\hline 1441 & body & g & $\mathrm{B}$ & I/E SM & 6.2 & $\begin{array}{l}3+\text { curvilinear engraved } \\
\text { lines }\end{array}$ & \\
\hline 1442 & body & $\mathrm{g}$ & F & I SM & 10.2 & $\begin{array}{l}\text { single rectilinear incised } \\
\text { line }\end{array}$ & \\
\hline 1448 & body & $g-b$ & G & I SM & 9.9 & $\begin{array}{l}2+\text { diagonal incised lines, } \\
\text { widely-spaced }\end{array}$ & \\
\hline 1470 & body & $\mathrm{g}$ & A & - & 4.3 & opposed incised lines & \\
\hline 1472 & body & g-o & $\mathrm{F}$ & I/E SM & 7.2 & opposed incised lines & \\
\hline
\end{tabular}


Lot No. Sherd type Temper FC ST $\quad$ T

Th Decoration

Comments

(mm)

\begin{tabular}{|c|c|c|c|c|c|c|c|}
\hline 1481 & $\operatorname{rim}(\mathrm{D}-\mathrm{Ro})$ & $\mathrm{g}$ & $\mathrm{B}$ & - & 5.2 & $\begin{array}{l}\text { single horizontal incised } \\
\text { line }\end{array}$ & \\
\hline 2006 & $\operatorname{rim}(\mathrm{D}-\mathrm{Ro})$ & $\mathrm{g}$ & G & E SM & 7.3 & $\begin{array}{l}\text { horizontal and diagonal } \\
\text { incised lines }\end{array}$ & $\mathrm{OD}=12+\mathrm{cm}$ \\
\hline 2038 & body & $\mathrm{g}$ & A & I/E SM & 5.2 & opposed incised lines & \\
\hline 2039 & body & $\mathrm{g}$ & $\mathrm{B}$ & I SM & 6.3 & $3+$ parallel incised lines & \\
\hline 2045 & body & $\mathrm{g}$ & $\mathrm{B}$ & E SM & 5.8 & $\begin{array}{l}\text { horizontal and opposed } \\
\text { engraved lines }\end{array}$ & \\
\hline 2071 & $\operatorname{rim}(\mathrm{D}-\mathrm{Ro})$ & $\mathrm{g}$ & $\mathrm{F}$ & $\mathrm{I} / \mathrm{E} \mathrm{B}$ & 4.3 & $\begin{array}{l}\text { horizontal and diagonal } \\
\text { incised lines }\end{array}$ & \\
\hline 2089 & body & $\mathrm{g}$ & $\mathrm{G}$ & I/E SM & 5.2 & $\begin{array}{l}\text { parallel engraved lines, } \\
\text { widely-spaced }\end{array}$ & \\
\hline 2090 & body & $g-b-h$ & $\mathrm{~A}$ & - & 5.2 & $3+$ parallel incised lines & \\
\hline 2098 & body & $\mathrm{g}$ & $\mathrm{B}$ & - & 5.1 & $\begin{array}{l}\text { circular incised zone } \\
\text { filled with small circular } \\
\text { punctations }\end{array}$ & $\begin{array}{l}\text { cf. Crockett } \\
\text { Curvilinear } \\
\text { Incised }\end{array}$ \\
\hline 2106 & body & $\mathrm{b}$ & $\mathrm{B}$ & $\mathrm{I} / \mathrm{E} \mathrm{B}$ & 5.0 & $\begin{array}{l}2+\text { parallel engraved } \\
\text { lines, widely-spaced }\end{array}$ & \\
\hline 2133 & rim (D-Ro) & $g-b$ & $\mathrm{~B}$ & $\mathrm{I} / \mathrm{E} \mathrm{SM}$ & 4.2 & $\begin{array}{l}3+\text { horizontal engraved } \\
\text { lines }\end{array}$ & \\
\hline 2145 & body & $b-o$ & G & - & 7.4 & $\begin{array}{l}2+\text { curvilinear engraved } \\
\text { lines }\end{array}$ & \\
\hline 2172 & body & $\mathrm{g}$ & $\mathrm{B}$ & I/E SM & 7.0 & $\begin{array}{l}2+\text { parallel engraved } \\
\text { lines }\end{array}$ & \\
\hline 2179 & body & $\mathrm{b}$ & $\mathrm{F}$ & I SM & 7.1 & $4+$ pinched rows & \\
\hline 2195 & body & $\mathrm{g}$ & $\mathrm{B}$ & - & 5.1 & $\begin{array}{l}2+\text { rows of small } \\
\text { circular punctations }\end{array}$ & \\
\hline 2197 & body & $\mathrm{g}$ & $\mathrm{G}$ & I SM & 3.4 & $2+$ cane punctated rows & \\
\hline 2201 & body & $\mathrm{b}$ & G & E B & 5.4 & $\begin{array}{l}2+\text { curvilinear engraved } \\
\text { lines, widely-spaced }\end{array}$ & Bottle \\
\hline 2224 & body & $g-b$ & A & I/E SM & 4.5 & $\begin{array}{l}\text { rectangular incised zone } \\
\text { filled with tool punctations }\end{array}$ & \\
\hline 2245 & body & $\mathrm{b}$ & $\mathrm{C}$ & - & 5.4 & opposed engraved lines & Bottle \\
\hline 2261 & body & $\mathrm{g}$ & G & - & 5.3 & $\begin{array}{l}\text { parallel incised lines, } \\
\text { closely-spaced }\end{array}$ & \\
\hline 2269 & body & $\mathrm{g}$ & $\mathrm{G}$ & - & 6.2 & $\begin{array}{l}\text { straight incised zone } \\
\text { filled with tool punctations }\end{array}$ & \\
\hline 2272 & body & $\mathrm{g}$ & A & - & 5.4 & $2+$ parallel incised lines & \\
\hline 2291 & body & $g-b$ & $\mathrm{~B}$ & $\begin{array}{l}\text { E B/ } \\
\text { I SM }\end{array}$ & 4.1 & $\begin{array}{l}\text { straight and opposed } \\
\text { engraved lines, closely- } \\
\text { spaced }\end{array}$ & \\
\hline 2321 & body & $\mathrm{g}$ & A & - & 9.7 & hatched engraved zone & \\
\hline 2326 & body & $\mathrm{g}$ & $\mathrm{E}$ & - & 11.0 & single straight incised line & \\
\hline 2329 & body & $\mathrm{g}$ & $\mathrm{B}$ & - & 5.5 & single straight incised line & \\
\hline \multirow[t]{2}{*}{2330} & body & $\mathrm{b}$ & $\mathrm{F}$ & - & 7.9 & $2+$ pinched rows & \\
\hline & $\operatorname{rim}(\mathrm{D}-\mathrm{Ro})$ & $\mathrm{g}$ & $\mathrm{B}$ & I SM & 6.6 & $2+$ horizontal incised lines & \\
\hline 2342 & body & $\mathrm{b}$ & $\mathrm{F}$ & - & 8.3 & $7+$ pinched rows & \\
\hline 2347 & body & $b-h$ & $\mathrm{G}$ & E SM & 4.9 & $\begin{array}{l}4+\text { parallel engraved } \\
\text { lines, widely-spaced }\end{array}$ & Bottle \\
\hline 2350 & body & $b-g$ & $\mathrm{G}$ & E SM & 4.9 & $\begin{array}{l}2+\text { parallel engraved lines, } \\
\text { widely-spaced }\end{array}$ & \\
\hline 2360 & body & $\mathrm{g}$ & $\mathrm{B}$ & - & 6.2 & single straight incised line & \\
\hline
\end{tabular}




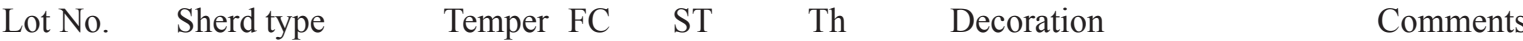
$(\mathrm{mm})$

\begin{tabular}{|c|c|c|c|c|c|c|c|}
\hline 2422 & body & $\mathrm{b}$ & G & - & 5.2 & $\begin{array}{l}\text { incised zone } \\
\text { filled with cane punctates }\end{array}$ & $\begin{array}{l}\text { cf. Crockett } \\
\text { Curvilinear }\end{array}$ \\
\hline $2440-2$ & body & $\mathrm{b}$ & $\mathrm{B}$ & - & 11.0 & vertical pinched rows & Incised \\
\hline 2451 & body & g & $\mathrm{H}$ & E SM & 4.6 & $\begin{array}{l}\text { triangular incised zone } \\
\text { filled with small circular } \\
\text { punctations }\end{array}$ & $\begin{array}{l}\text { cf. Crockett/ } \\
\text { Pennington }\end{array}$ \\
\hline 2471 & body & g & $\mathrm{F}$ & E SM & 5.6 & $\begin{array}{l}4+\text { horizontal engraved } \\
\text { lines on the neck }\end{array}$ & $\begin{array}{l}\text { Bottle; } \\
\text { Holly Fine } \\
\text { Engraved }\end{array}$ \\
\hline 2522 & body & $\mathrm{g}$ & G & E SM & 5.7 & $\begin{array}{l}\text { multiple engraved lines, } \\
\text { closely-spaced }\end{array}$ & \\
\hline 2560 & rim (INV-Ro) & $\mathrm{g}$ & $\mathrm{F}$ & - & 8.9 & $\begin{array}{l}\text { single broad horizontal } \\
\text { incised line; incised line } \\
\text { on the lip; Coles Creek } \\
\text { Incised }\end{array}$ & \\
\hline 2561 & body & $b-g$ & G & I/E SM & 4.6 & single straight incised line & \\
\hline \multirow[t]{2}{*}{2566} & body & b-g & $\mathrm{G}$ & I SM & 7.2 & $4+$ pinched rows & \\
\hline & body & g & G & E B & 5.9 & $\begin{array}{l}6+\text { curvilinear engraved } \\
\text { lines, closely-spaced }\end{array}$ & \\
\hline \multirow[t]{2}{*}{2570} & body & $\mathrm{g}$ & $\mathrm{B}$ & E SM & 6.0 & opposed incised lines & \\
\hline & body & $\mathrm{g}$ & B & - & 5.7 & $\begin{array}{l}\text { sets of opposed incised } \\
\text { lines }\end{array}$ & $\begin{array}{l}\text { cf. Crockett } \\
\text { Curvilinear } \\
\text { Incised }\end{array}$ \\
\hline 2572 & $\begin{array}{l}\text { body } \\
\text { incised line }\end{array}$ & g & $\mathrm{H}$ & - & 6.7 & single straight and broad & \\
\hline 2578 & body & $b-g$ & G & I SM & 8.9 & single straight incised line & \\
\hline 2586 & body & g & $\mathrm{B}$ & - & 6.5 & $3+$ parallel incised lines & \\
\hline 2600 & body & g & G & E SM & 3.7 & $\begin{array}{l}2+\text { parallel engraved lines, } \\
\text { widely-spaced }\end{array}$ & \\
\hline 2605 & body & g & G & E SM & 6.0 & opposed engraved lines & \\
\hline V20 & body & $\mathrm{g}$ & G & E SM & 6.0 & $\begin{array}{l}8+\text { curvilinear engraved } \\
\text { lines }\end{array}$ & Bottle? \\
\hline V21 & body & g & $\mathrm{B}$ & - & 6.3 & $\begin{array}{l}7+\text { parallel incised lines, } \\
\text { closely-spaced }\end{array}$ & $\mathrm{SP}$ \\
\hline \multirow[t]{2}{*}{ V32 } & body & g & A & - & 7.9 & $\begin{array}{l}\text { single straight incised } \\
\text { line }\end{array}$ & \\
\hline & body & g & $\mathrm{B}$ & - & 5.9 & $\begin{array}{l}\text { parallel engraved lines, } \\
\text { closely-spaced }\end{array}$ & \\
\hline V44 & body & g & G & - & 5.4 & $\begin{array}{l}3+\text { parallel incised lines, } \\
\text { closely-spaced }\end{array}$ & \\
\hline V48 & body & g-b & G & - & 8.8 & $\begin{array}{l}2+\text { parallel incised lines, } \\
\text { closely-spaced }\end{array}$ & \\
\hline V49 & rim (D-Ro) & $\mathrm{g}$ & $\mathrm{F}$ & - & 4.8 & $\begin{array}{l}\text { single horizontal incised } \\
\text { line; incised line on lip; } \\
\text { Coles Creek Incised }\end{array}$ & \\
\hline V49 & body & $\mathrm{g}$ & $\mathrm{G}$ & - & 6.8 & $\begin{array}{l}6+\text { parallel incised lines, } \\
\text { closely-spaced }\end{array}$ & \\
\hline V51 & body & g-b & G & - & 6.0 & $\begin{array}{l}\text { Incised scroll el.; } \\
\text { Crockett Curvilinear } \\
\text { Incised }\end{array}$ & \\
\hline V61 & body & $g-b$ & $\mathrm{~B}$ & I SM & 8.1 & $3+$ pinched rows & SP \\
\hline V65 & body & g & $\mathrm{G}$ & - & 7.7 & $\begin{array}{l}\text { single straight incised } \\
\text { line }\end{array}$ & \\
\hline
\end{tabular}




\begin{tabular}{|c|c|c|c|c|c|c|c|}
\hline Lot No. & Sherd type & Temper & $\mathrm{FC}$ & $\mathrm{ST}$ & $\begin{array}{l}\text { Th } \\
(\mathrm{mm})\end{array}$ & Decoration & Comments \\
\hline V84 & body & g & B & - & 6.0 & Incised scroll el; & $\begin{array}{l}\text { Crockett } \\
\text { Curvilinear } \\
\text { Incised }\end{array}$ \\
\hline \multirow[t]{2}{*}{ V103 } & $\operatorname{rim}(\mathrm{D}-\mathrm{Ro})$ & $\mathrm{g}$ & G & E SM & 4.1 & $\begin{array}{l}\text { single horizontal engraved } \\
\text { line }\end{array}$ & \\
\hline & body & g & G & E SM & 4.4 & $\begin{array}{l}\text { single straight engraved } \\
\text { line }\end{array}$ & \\
\hline V108 & body & g & B & E SM & 4.8 & $2+$ parallel incised lines & \\
\hline
\end{tabular}

*Rim Form: D=direct; INV=inverted; EV=everted; Lip: Ro=rounded; FL=flat; ext f=exterior folded; exp=expanded Temper: $\mathrm{b}=$ bone; $\mathrm{g}=$ grog; $\mathrm{h}=$ hematite; $\mathrm{o}=$ organics; $\mathrm{SP}=$ sandy paste

$\mathrm{FC}=$ firing conditions, follow Teltser (1993:Figure 2) and Perttula (2005:Figure 5-30)

$\mathrm{ST}=$ surface treatment; $\mathrm{E}=$ exterior; $\mathrm{SM}=$ smoothed; $\mathrm{B}=$ burnished

$\mathrm{Th}=$ thickness; $\mathrm{OD}=$ orifice diameter 


\section{Appendix 2,}

Detailed Analysis of Plain Rim Sherds from the Stallings Site

\begin{tabular}{|c|c|c|c|c|c|c|c|}
\hline Lot No. & Rim-Lip Form & Temper & $\mathrm{FC}$ & ST & $\begin{array}{l}\text { Th } \\
(\mathrm{mm})\end{array}$ & $\begin{array}{l}\mathrm{OD} \\
(\mathrm{cm})\end{array}$ & Comments \\
\hline 1015 & D-FL & g-b & $\mathrm{F}$ & - & 7.7 & - & \\
\hline 1030 & D-Ro & g-h & $\mathrm{G}$ & I SM & 8.8 & - & \\
\hline 1033 & D-FL & b-h & $\mathrm{G}$ & $\mathrm{I} / \mathrm{E} \mathrm{SM}$ & 6.3 & - & \\
\hline \multirow[t]{2}{*}{1046} & -Ro & $\mathrm{g}$ & $\mathrm{G}$ & - & 4.3 & - & \\
\hline & D-Ro & $\mathrm{g}$ & $\mathrm{B}$ & - & 6.5 & - & \\
\hline 1050 & -Ro & $\begin{array}{l}8 \\
\mathrm{~g}\end{array}$ & $\mathrm{G}$ & - & 7.7 & - & \\
\hline 1053 & D-Ro & $\begin{array}{l}\mathrm{g} \\
\mathrm{g}\end{array}$ & $\mathrm{F}$ & - & 7.0 & - & \\
\hline 1061 & -Ro & g & $\mathrm{B}$ & - & 6.3 & - & \\
\hline 1062 & D-FL & $\begin{array}{l}8 \\
\mathrm{~g}\end{array}$ & A & $\mathrm{I} / \mathrm{E} \mathrm{SM}$ & 7.2 & $14+$ & \\
\hline 1064 & EV-Ro & g-h & $\mathrm{E}$ & - & 11.0 & - & \\
\hline \multirow[t]{2}{*}{1094} & D-Ro & $\mathrm{g}$ & $\mathrm{F}$ & - & 7.5 & - & \\
\hline & D-FL & g & $\mathrm{B}$ & - & 8.0 & $15+$ & \\
\hline 1125 & D-Ro & g-b & $\mathrm{B}$ & $\mathrm{I} / \mathrm{E} \mathrm{SM}$ & 7.2 & $11+$ & \\
\hline \multirow[t]{3}{*}{1180} & - Ro & $\mathrm{g}$ & $\mathrm{F}$ & - & 6.4 & - & \\
\hline & D-Ro, ext f & $\mathrm{g}$ & $\mathrm{G}$ & I SM & 7.5 & - & \\
\hline & D-Ro & g-b & $\mathrm{G}$ & - & 7.3 & - & \\
\hline 1185 & D-Ro & $\mathrm{b}$ & $\mathrm{G}$ & - & 7.1 & - & \\
\hline 1203 & EV-Ro & $\mathrm{g}$ & B & E SM & 8.4 & 23 & \\
\hline 1210 & D-Ro & $\mathrm{g}$ & $\mathrm{G}$ & - & 6.7 & - & \\
\hline 1226 & D-Ro & $\mathrm{g}$ & $\mathrm{G}$ & $\mathrm{I} / \mathrm{E} \mathrm{B}$ & 8.4 & - & \\
\hline 1243 & D-FL & g-b & $\mathrm{G}$ & - & 7.3 & - & \\
\hline 1262 & -Ro & g-o & $\mathrm{G}$ & $\mathrm{I} / \mathrm{E} \mathrm{SM}$ & 8.6 & - & \\
\hline 1304 & EV-Ro & $\mathrm{g}$ & $\mathrm{F}$ & I SM & 7.6 & 16 & \\
\hline 1365 & D-FL & g-b & $\mathrm{C}$ & - & 8.0 & $15+$ & \\
\hline 1372 & -Ro & g-h & $\mathrm{G}$ & $\mathrm{I} / \mathrm{E} \mathrm{SM}$ & 5.2 & - & \\
\hline 1384 & D-Ro & $\mathrm{g}$ & $\mathrm{G}$ & - & 8.8 & - & \\
\hline 1392 & D-Ro & $\mathrm{g}$ & $\mathrm{G}$ & - & 7.2 & $22+$ & \\
\hline 1405 & -Ro & $\mathrm{g}$ & A & - & 7.2 & - & \\
\hline 1440 & D-Ro & g-o & $\mathrm{F}$ & - & 8.6 & - & \\
\hline 1442 & D-Ro & g & $\mathrm{G}$ & - & 6.0 & - & SP \\
\hline 1451 & -Ro & g-b-h & $\mathrm{F}$ & I SM & 6.9 & - & \\
\hline 1466 & -Ro & $\mathrm{g}$ & A & - & 5.6 & - & \\
\hline 1469 & D-Ro & $\mathrm{g}$ & $\mathrm{C}$ & - & 5.1 & $17+$ & \\
\hline 1479 & D-FL & $\mathrm{g}$ & $\mathrm{F}$ & - & 7.2 & - & \\
\hline \multirow[t]{2}{*}{1496} & -Ro & $\mathrm{g}$ & A & - & 5.7 & - & \\
\hline & D-FL & g-h & $\mathrm{F}$ & - & 8.2 & $10+$ & \\
\hline 2023 & -Ro & $\mathrm{g}$ & B & I SM & 6.3 & - & \\
\hline 2044 & -Ro & $\mathrm{g}$ & A & - & 6.5 & - & \\
\hline 2054 & D-Ro & $\mathrm{g}$ & B & - & 8.6 & - & \\
\hline 2070 & -Ro & $\mathrm{g}$ & A & - & 5.9 & - & \\
\hline 2075 & $-F L$ & $\mathrm{~g}$ & $\mathrm{C}$ & - & 6.0 & - & \\
\hline 2082 & D-Ro & $\mathrm{b}$ & B & - & 7.2 & & \\
\hline 2098 & D-Ro & g-b & $\mathrm{F}$ & - & 5.7 & - & \\
\hline
\end{tabular}


Lot No. Rim-Lip Form $\quad$ Temper $\quad$ FC $\quad$ ST $\quad$ Th $\quad$ OD Comments

\begin{tabular}{|c|c|c|c|c|c|c|c|}
\hline 2102 & D-Ro & g & $\mathrm{B}$ & - & 8.2 & - & \\
\hline 2129 & D-Ro & $g-b$ & $\mathrm{G}$ & E SM & 6.2 & $16+$ & \\
\hline 2138 & D-Ro & $\mathrm{g}$ & $\mathrm{G}$ & - & 5.0 & & \\
\hline 2139 & D-Ro & g-b & B & - & 7.1 & $17+$ & \\
\hline 2140 & INV-Ro & g & A & - & 8.6 & - & \\
\hline 2140 & -Ro & $\mathrm{g}$ & B & - & 6.2 & - & \\
\hline 2140 & D-Ro & g & $\mathrm{E}$ & E SM & 6.2 & - & \\
\hline 2140 & D-Ro & g & $\mathrm{H}$ & I/E SM & 9.2 & 30 & \\
\hline 2144 & INV-Ro & g & $\mathrm{C}$ & E SM & 8.3 & - & SP \\
\hline $2159-1$ & D-FL & g-b & $\mathrm{H}$ & E SM & 10.3 & 26 & \\
\hline 2169 & D-Ro & g & $\mathrm{C}$ & - & 8.9 & $18+$ & \\
\hline \multirow{2}{*}{2175} & D-Ro & g & B & - & 7.2 & - & \\
\hline & D-FL, ext f & g-o & $\mathrm{F}$ & - & 5.8 & - & \\
\hline 2195 & D-Ro & g & A & I SM & 8.0 & - & \\
\hline 2197 & $-F L$ & g & A & - & 8.4 & - & \\
\hline 2217 & D-Ro & g & $\mathrm{F}$ & I SM & 7.6 & - & \\
\hline 2218 & $-F L$ & $\mathrm{~g}-\mathrm{b}$ & $\mathrm{H}$ & - & 5.1 & - & \\
\hline \multirow[t]{2}{*}{2223} & D-FL & $\mathrm{g}$ & $\mathrm{F}$ & E SM & 6.4 & - & \\
\hline & -Ro & $\mathrm{g}$ & $\mathrm{F}$ & - & 5.7 & - & \\
\hline 2240 & EV-FL & g-b & $\mathrm{H}$ & I/E SM & 7.1 & $11+$ & \\
\hline 2270 & D-Ro & $\mathrm{g}-\mathrm{b}$ & B & - & 6.5 & $16+$ & \\
\hline 2285 & D-Ro & $\mathrm{g}$ & G & E SM & 10.2 & - & \\
\hline 2312 & D-FL & $\mathrm{g}$ & G & - & 9.1 & - & \\
\hline 2328 & D-Ro & g & $\mathrm{F}$ & I SM & 7.2 & - & \\
\hline 2336 & D-FL & g-h & $\mathrm{H}$ & - & 6.7 & - & \\
\hline \multirow[t]{3}{*}{2338} & - Ro & $\mathrm{g}$ & A & - & 5.3 & - & \\
\hline & D-Ro & $\mathrm{g}-\mathrm{O}$ & G & I SM & 6.8 & - & \\
\hline & D-FL & $\mathrm{g}$ & B & - & 6.3 & - & \\
\hline 2340 & D-FL, exp & $\mathrm{g}$ & $\mathrm{F}$ & - & 5.7 & - & \\
\hline \multirow[t]{2}{*}{2350} & D-Ro & g-b & B & - & 5.9 & - & \\
\hline & - Ro & g-b & $\mathrm{F}$ & E SM & 6.4 & - & \\
\hline 2356 & D-Ro & g-o & B & - & 7.5 & - & \\
\hline 2364 & D-Ro & g-b & $\mathrm{F}$ & - & 6.0 & - & \\
\hline 2391 & D-FL & $\mathrm{g}$ & B & I/E SM & 7.2 & - & \\
\hline 2394 & - Ro & $\mathrm{g}$ & B & - & 8.6 & - & \\
\hline 2447 & EV-Ro & g & A & - & 4.6 & - & \\
\hline 2486 & EV-FL & b-g & $\mathrm{F}$ & - & 8.8 & $18+$ & \\
\hline 2509 & $-F L$ & $\mathrm{~g}-\mathrm{b}$ & G & - & 7.4 & - & \\
\hline 2534 & D-FL, exp & g-b-h & $\mathrm{C}$ & - & 5.9 & - & \\
\hline 2552 & D-Ro & g-h & G & I SM & 6.7 & $15+$ & \\
\hline 2587 & - Ro & $\mathrm{g}$ & G & - & 8.0 & - & \\
\hline 2594 & D-Ro & g & $\mathrm{C}$ & - & 6.5 & - & \\
\hline 2600 & D-FL & g & $\mathrm{F}$ & I/E SM & 8.1 & - & \\
\hline 2605 & D-FL & $g-b$ & $\mathrm{~F}$ & - & 7.4 & $13+$ & \\
\hline V38 & - Ro & b-h & G & - & 6.3 & - & \\
\hline \multirow[t]{2}{*}{ V44 } & D-Ro & $\mathrm{g}$ & A & - & 4.4 & - & \\
\hline & D-Ro & $\mathrm{g}$ & $\mathrm{G}$ & - & 5.2 & - & \\
\hline
\end{tabular}




\begin{tabular}{llllllll} 
Lot No. & Rim-Lip Form & Temper & FC & ST & $\begin{array}{l}\text { Th } \\
(\mathrm{mm})\end{array}$ & $\begin{array}{l}\text { OD } \\
(\mathrm{cm})\end{array}$ & Comments \\
\hline & & & & & & & \\
V49 & D-Ro & g & G & I SM & 7.2 & - & \\
V62 & -Ro & g-b & B & - & 4.1 & - & \\
V63 & D-Ro & g & A & - & 6.5 & - & \\
V65 & D-Ro & g-b & G & - & 7.9 & - & \\
V76 & D-FL & b & F & E SM & 9.2 & 31 & \\
V105 & -Ro & g & G & I/E SM & 5.0 & - & \\
V109 & D-FL & g & F & - & 7.7 & $15+$ & \\
V112 & D-Ro & g & G & - & 7.2 & $19+$ & SP \\
Y1338-5 & D-Ro & g & B & - & 6.6 & - & -
\end{tabular}

*Rim Form: D=direct; INV=inverted; EV=everted; Lip: Ro=rounded; FL=flat; ext f=exterior folded; exp=expanded Temper: $\mathrm{b}=$ bone; $\mathrm{g}=$ grog; $\mathrm{h}=$ hematite; $\mathrm{o}=$ organics; $\mathrm{SP}=$ sandy paste $\mathrm{FC}=$ firing conditions, follow Teltser (1993:Figure 2)

ST=surface treatment; E=exterior; $\mathrm{SM}=$ smoothed; $\mathrm{B}=$ burnished $\mathrm{Th}=$ thickness; $\mathrm{OD}=$ orifice diameter 
Appendix 3,

Detailed Analysis of Clay Pipe Sherds from the Stallings Site

\begin{tabular}{|c|c|c|c|c|c|c|c|c|}
\hline Lot No. & Sherd Type & Temper & $\mathrm{FC}$ & $\mathrm{ST}$ & $\begin{array}{l}\text { Th } \\
(\mathrm{mm})\end{array}$ & $\begin{array}{l}\text { EOD } \\
(\mathrm{mm})\end{array}$ & $\begin{array}{l}\text { IOD } \\
(\mathrm{mm})\end{array}$ & Comments \\
\hline 221 & pipe stem & $\mathrm{b}$ & A & E SM & 1.2 & - & - & \\
\hline 1030 & pipe stem & $\mathrm{b}$ & G & E SM & 0.8 & 7.2 & 3.1 & \\
\hline 1031 & bowl rim & $\mathrm{b}$ & G & E SM & 1.5 & - & - & D-Ro \\
\hline \multirow[t]{2}{*}{1039} & pipe stem & $\mathrm{b}$ & G & E SM & 1.8 & - & - & \\
\hline & $\begin{array}{l}\text { pipe stem at } \\
\text { bowl attachment }\end{array}$ & $\mathrm{b}$ & A & E B & 1.1 & 7.1 & 3.0 & \\
\hline 1094 & pipe stem & $\mathrm{b}$ & B & - & 0.9 & 6.5 & 2.1 & \\
\hline 1123 & pipe stem & $\mathrm{b}$ & B & - & 1.8 & 7.3 & 1.8 & \\
\hline 1129 & $\begin{array}{l}\text { pipe stem and } \\
\text { lower bowl }\end{array}$ & $\mathrm{b}$ & G & - & $1.3-2.1$ & 7.2 & 3.1 & \\
\hline 1196 & $\begin{array}{l}\text { pipe stem with } \\
\text { blunt end }\end{array}$ & $\mathrm{g}$ & A & - & 1.1 & 8.0 & 2.4 & \\
\hline 1232 & $\begin{array}{l}\text { pipe stem, poss. } \\
\text { blunt end }\end{array}$ & $\mathrm{g}$ & A & - & - & 7.2 & 1.9 & \\
\hline 1245 & pipe stem & $\mathrm{b}$ & B & - & 1.7 & 8.3 & 3.6 & \\
\hline 1247 & pipe stem & $\mathrm{b}$ & $\mathrm{B}$ & - & 1.4 & 6.9 & 2.1 & \\
\hline 1250 & bowl rim & $\mathrm{b}$ & B & - & 3.1 & 20.0 & - & D-Ro \\
\hline 1276 & pipe stem & $\mathrm{b}$ & B & - & 1.3 & 8.0 & 2.4 & \\
\hline 1328 & pipe stem & $\mathrm{b}$ & A & E SM & 1.4 & 7.7 & 2.8 & \\
\hline 1372 & pipe stem & $\mathrm{b}$ & A & E B & 1.5 & 6.3 & 2.5 & \\
\hline 1407 & bowl rim & $\mathrm{g}$ & B & E SM & 1.8 & - & - & D-Ro \\
\hline $1432-1$ & $\begin{array}{l}\text { pipe stem and } \\
\text { lower bowl; stem } \\
\text { has blunt end }\end{array}$ & $\mathrm{g}$ & B & - & 1.3 & 7.7 & 2.8 & \\
\hline 1436 & bowl rim & $\mathrm{b}$ & G & E SM & 1.8 & - & - & D-Ro \\
\hline 1459 & pipe stem & $\mathrm{b}$ & $\mathrm{F}$ & - & 1.2 & - & - & \\
\hline 1466 & $\begin{array}{l}\text { pipe stem with } \\
\text { blunt end }\end{array}$ & $\mathrm{b}$ & G & E SM & 1.8 & 7.4 & 2.3 & \\
\hline 1491 & pipe bowl & $\mathrm{b}$ & G & - & 4.2 & 15.9 & - & $\begin{array}{l}\text { bowl ht. is } \\
16.2 \mathrm{~mm}+\text {; stem } \\
\text { EOD }=8.8 \mathrm{~mm} ; \\
\text { stem } \mathrm{IOD}=1.9 \mathrm{~mm}\end{array}$ \\
\hline 1497 & pipe bowl & $\mathrm{b}$ & G & E SM & 1.6 & - & - & \\
\hline 2003 & pipe stem rim & $\mathrm{g}$ & B & - & 1.4 & - & 2.2 & D-FL \\
\hline 2068 & bowl rim & $\mathrm{b}$ & G & E SM & 1.1 & - & - & D-Ro \\
\hline \multirow[t]{2}{*}{2078} & pipe stem & $\mathrm{b}$ & G & - & 1.3 & 6.3 & 2.3 & \\
\hline & & $\mathrm{b}$ & G & E SM & 1.2 & 7.6 & 2.0 & \\
\hline 2079 & pipe stem & $\mathrm{b}$ & G & - & 1.3 & - & - & \\
\hline 2080 & pipe stem & $\mathrm{g}$ & B & E SM & 1.2 & 7.5 & 3.1 & \\
\hline 2093 & pipe stem & $b-g$ & A & E SM & 1.1 & 6.6 & 2.5 & \\
\hline \multirow[t]{2}{*}{2108} & pipe stem & $\mathrm{b}$ & G & E SM & 1.2 & 6.1 & 2.1 & \\
\hline & $\begin{array}{l}\text { pipe stem with } \\
\text { blunt end }\end{array}$ & $\mathrm{g}$ & B & - & 1.2 & 7.9 & 2.5 & \\
\hline \multirow[t]{2}{*}{2140} & pipe stem & $\mathrm{g}$ & $\mathrm{B}$ & E SM & 2.0 & 7.2 & 2.0 & \\
\hline & & $\mathrm{g}$ & B & E SM & 2.0 & 7.5 & 2.3 & \\
\hline 2170 & pipe stem & $\mathrm{g}$ & A & - & 1.3 & 7.6 & 3.2 & \\
\hline 2174 & pipe stem & $\mathrm{b}$ & B & - & 1.3 & 8.9 & 3.0 & \\
\hline
\end{tabular}


Lot No. Sherd Type

Temper FC ST Th $\quad$ EOD IOD Comments (mm) $(\mathrm{mm}) \quad(\mathrm{mm})$

\begin{tabular}{|c|c|c|c|c|c|c|c|c|}
\hline 2180 & pipe stem & $\mathrm{b}$ & $\mathrm{G}$ & E B & 1.2 & 8.4 & 3.8 & \\
\hline 2182 & pipe stem & $\mathrm{b}$ & $\mathrm{G}$ & E SM & 1.3 & 7.6 & 2.8 & \\
\hline 2233 & pipe stem & $\mathrm{b}$ & $\mathrm{G}$ & - & 1.3 & 7.2 & 2.7 & \\
\hline 2243 & pipe stem & $\mathrm{b}$ & $\mathrm{B}$ & - & 1.3 & 7.6 & 2.5 & \\
\hline \multirow[t]{3}{*}{2270} & bowl rim & $\mathrm{g}$ & $\mathrm{B}$ & E SM & 3.6 & - & - & \\
\hline & pipe stem & $\mathrm{b}$ & A & - & 1.7 & 8.4 & 2.6 & \\
\hline & $\begin{array}{l}\text { pipe stem with } \\
\text { blunt end }\end{array}$ & $\mathrm{g}$ & $\mathrm{B}$ & - & 2.3 & 9.4 & 2.3 & \\
\hline 2316 & pipe stem & $\mathrm{b}$ & $\mathrm{A}$ & - & 1.5 & 8.0 & 3.4 & \\
\hline 2324 & pipe stem & $\mathrm{b}$ & $\mathrm{F}$ & E B & 1.3 & 7.7 & 2.2 & \\
\hline $2364-1$ & pipe stem & $\mathrm{g}$ & $\mathrm{G}$ & E SM & 1.5 & 7.0 & 1.7 & \\
\hline 2429 & pipe stem & $\mathrm{g}$ & $\mathrm{B}$ & E SM & 1.3 & 7.2 & - & \\
\hline 2439 & pipe stem & $\mathrm{b}$ & $\mathrm{F}$ & - & 1.0 & - & - & \\
\hline 2497 & pipe stem & $\mathrm{b}$ & $\mathrm{G}$ & E SM & 1.8 & 8.2 & - & \\
\hline 2531 & bowl rim & $\mathrm{b}$ & $\mathrm{F}$ & E SM & 1.1 & - & - & D-Ro \\
\hline \multirow[t]{3}{*}{2540} & pipe stem & $\mathrm{b}$ & G & - & 1.7 & 8.2 & 3.0 & \\
\hline & pipe stem & $\mathrm{g}$ & $\mathrm{G}$ & E SM & 2.2 & 8.2 & 2.4 & \\
\hline & pipe stem & $\mathrm{g}$ & G & E SM & 2.0 & 8.4 & 2.4 & \\
\hline \multirow[t]{2}{*}{2561} & pipe stem & $\mathrm{g}$ & $\mathrm{B}$ & - & 1.5 & 9.0 & 3.8 & \\
\hline & pipe stem & $\mathrm{b}$ & $\mathrm{B}$ & - & 1.0 & 8.2 & 2.5 & \\
\hline \multirow[t]{2}{*}{2598} & pipe stem & $\mathrm{b}$ & $\mathrm{G}$ & - & 0.9 & 6.8 & 2.1 & \\
\hline & pipe stem & $\mathrm{b}$ & $\mathrm{G}$ & E SM & 1.2 & 7.3 & 2.5 & \\
\hline V19 & bowl rim & $\mathrm{b}$ & $\mathrm{G}$ & - & 2.8 & - & - & D-Ro \\
\hline V22 & $\begin{array}{l}\text { pipe stem with } \\
\text { blunt end }\end{array}$ & $\mathrm{g}$ & A & E B & 0.8 & 6.7 & 2.9 & \\
\hline V38 & pipe stem & $\mathrm{b}$ & G & E SM & 1.2 & 7.4 & 2.8 & \\
\hline V49 & pipe stem & $\mathrm{b}$ & $\mathrm{G}$ & - & 0.8 & 7.0 & 3.0 & \\
\hline V71 & pipe stem & $\mathrm{b}$ & $\mathrm{B}$ & E B & 1.2 & 7.9 & 2.5 & ext. slip \\
\hline \multirow[t]{2}{*}{ V94 } & pipe stem & $\mathrm{b}$ & G & - & 1.3 & 8.4 & 3.4 & \\
\hline & pipe stem & none & $\mathrm{B}$ & E SM & 0.5 & 7.4 & 3.3 & \\
\hline V100 & $\begin{array}{l}\text { pipe stem at } \\
\text { bowl attachment }\end{array}$ & $\mathrm{b}$ & A & - & 1.8 & 8.0 & 2.5 & \\
\hline \multirow[t]{2}{*}{ V107 } & pipe bowl & $\mathrm{g}$ & $\mathrm{A}$ & E SM & 2.8 & - & - & $\begin{array}{l}\text { bowl diam. }= \\
60.0 \mathrm{~mm}\end{array}$ \\
\hline & pipe stem & $\mathrm{g}$ & $\mathrm{B}$ & - & 1.7 & 7.7 & 2.5 & \\
\hline
\end{tabular}

*Rim: $\mathrm{D}=$ direct; Lip: $\mathrm{RO}=$ rounded; $\mathrm{FL}=$ flat

Temper: $\mathrm{b}=$ bone; $\mathrm{g}=$ grog

$\mathrm{FC}=$ firing conditions, follow Teltser (1993:Figure 2)

$\mathrm{ST}=$ surface treatment; $\mathrm{E}=$ exterior; $\mathrm{SM}=$ smoothed; $\mathrm{B}=$ burnished

$\mathrm{Th}=$ thickness; $\mathrm{EOD}=$ exterior orifice diameter; $\mathrm{IOD}=$ interior orifice diameter 